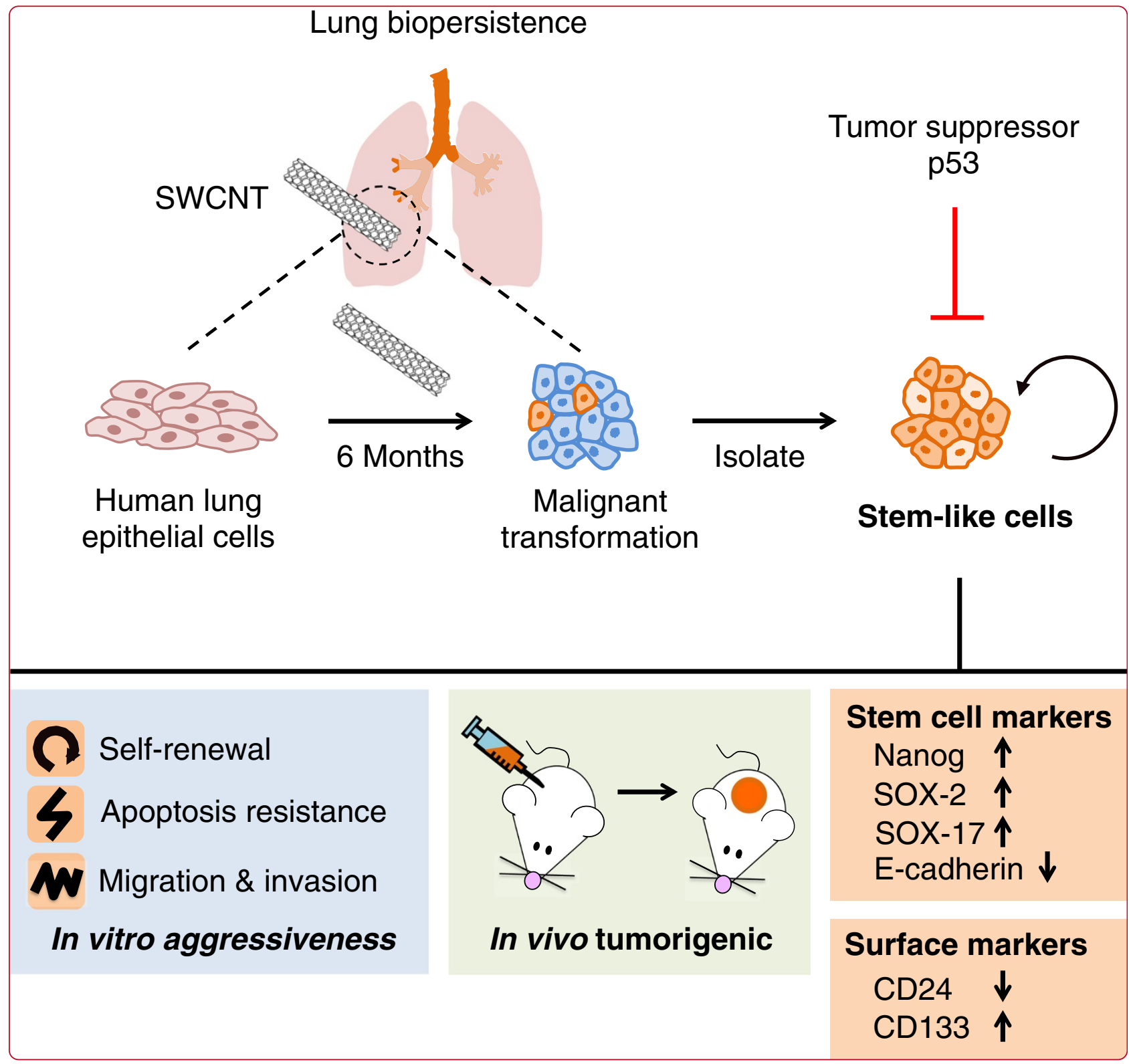

Induction of stem-like cells with malignant properties by chronic exposure of human lung epithelial cells to single-walled carbon nanotubes

Luanpitpong et al. 


\title{
Induction of stem-like cells with malignant properties by chronic exposure of human lung epithelial cells to single-walled carbon nanotubes
}

\author{
Sudjit Luanpitpong ${ }^{1,2}$, Liying Wang $^{3}$, Vincent Castranova ${ }^{3}$ and Yon Rojanasakul 1,2*
}

\begin{abstract}
Background: Carbon nanotubes (CNT) hold great promise to create new and better products for commercial and biomedical applications, but their long-term adverse health effects are a major concern. The objective of this study was to address human lung cancer risks associated with chronic pulmonary exposure to single-walled (SW) CNT through the fundamental understanding of cellular and molecular processes leading to carcinogenesis. We hypothesized that the acquisition of cancer stem cells (CSC), a subpopulation that drive tumor initiation and progression, may contribute to CNT carcinogenesis.
\end{abstract}

Methods: Non-tumorigenic human lung epithelial cells were chronically exposed to well-dispersed SWCNT for a period of 6 months at the physiologically relevant concentration of $0.02 \mu \mathrm{g} / \mathrm{cm}^{2}$ surface area dose. Chronic SWCNT-exposed cells were evaluated for the presence of CSC-like cells under CSC-selective conditions of tumor spheres and side population (SP). CSC-like cells were isolated using fluorescence-activated cell sorting and were assessed for aggressive behaviors, including acquired apoptosis resistance and increased cell migration and invasion in vitro, and tumor-initiating capability in vivo. Non-small cell lung cancer cells served as a positive control.

Results: We demonstrated for the first time the existence of CSC-like cells in all clones of chronic SWCNT-exposed lung epithelial cells. These CSC-like cells, in contrary to their non-CSC counterpart, possessed all biological features of lung CSC that are central to irreversible malignant transformation, self-renewal, aggressive cancer behaviors, and in vivo tumorigenesis. These cells also displayed aberrant stem cell markers, notably Nanog, SOX-2, SOX-17 and E-cadherin. Restored expression of tumor suppressor p53 abrogated CSC properties of CSC-like cells. Furthermore, we identified specific stem cell surface markers CD24 ${ }^{\text {low }}$ and CD133 $3^{\text {high }}$ that are associated with SWCNT-induced CSC formation and tumorigenesis.

Conclusions: Our findings provide new and compelling evidence for the acquisition of CSC-like cells induced by chronic SWCNT exposure, which are likely to be a major driving force for SWCNT tumorigenesis. Thus, our study supports prudent adoption of prevention strategies and implementation of exposure control for SWCNT. We also suggest that the detection of CSC and associated surface markers may provide an effective screening tool for prediction of the carcinogenic potential of SWCNT and related nanoparticles.

Keywords: Carbon nanotubes, Stem cells, Lung epithelial cells, Tumorigenesis, Malignant transformation

\footnotetext{
* Correspondence: yrojan@hsc.wvu.edu

${ }^{1}$ Pharmaceutical and Pharmacological Sciences Program, West Virginia

University, Morgantown, WV 26506, USA

${ }^{2}$ Mary Babb Randolph Cancer Center, West Virginia University, Morgantown,

WW 26506, USA

Full list of author information is available at the end of the article
}

\section{Biomed Central}

(c) 2014 Luanpitpong et al.; licensee BioMed Central Ltd. This is an Open Access article distributed under the terms of the Creative Commons Attribution License (http://creativecommons.org/licenses/by/2.0), which permits unrestricted use, distribution, and reproduction in any medium, provided the original work is properly credited. The Creative Commons Public Domain Dedication waiver (http://creativecommons.org/publicdomain/zero/1.0/) applies to the data made available in this article, unless otherwise stated. 


\section{Background}

Carbon nanotubes (CNT) are a major class of engineered nanomaterials that are being produced on a massive scale for a wide range of industrial and biomedical applications. Their rapid growth in utility is attributed to their unique properties such as light weight, high tensile strength, conductivity and flexibility $[1,2]$. The global market for CNT is estimated to reach trillion dollars in the next decade [3], and so will the increase in human exposure during manufacturing, consuming, and disposal. Despite this growing trend, their adverse health effects, especially long-term health effects, are relatively unknown. CNT share several properties (e.g. high aspect ratio, durability, and biopersistence) and route of exposure (e.g. respiratory) with asbestos fibers [4-6], which are known human lung carcinogens. Thus, CNT exposure may cause heath consequences similar to asbestos exposure, which include lung cancer and mesothelioma.

The lungs are the major target organ for airborne CNT exposure. CNT have been shown to migrate into the alveolar interstitial compartment where the clearance rate is low [7-9]. Recent animal studies have shown that inhaled CNT that penetrate lung tissue could persist in the lungs 6 months post-exposure [10]. Such biopersistence and chronic interaction with lung epithelial cells could potentially lead to carcinogenesis $[10,11]$ since biopersistence is a critical factor in the paradigm of hazardous fibers and is a basis for the classification of their carcinogenic potential $[12,13]$. The acute effects of highdose CNT have been widely studied. In vitro, CNT can induce apoptosis, DNA breakage, multipolar mitosis, and activation of key molecular events involved in carcinogenesis, e.g. MAPK, AP-1, NF-kB, and Akt [14-18]. In animals, a single intraperitoneal injection of multiwalled (MW) CNT in heterozygous p53 mice caused asbestos-like mesothelioma [19,20], while their shortterm intraperitoneal instillation in C57BL/6 mice induced granuloma formation [21]. Short-term inhalation of single-walled (SW) CNT was shown to trigger mutations of K-ras gene locus in the lung of C57BL/6 mice, which is a common event observed in lung tumors [22].

Unlike their acute effects, the chronic effects of CNT have not been well addressed due to technical difficulties and limited experimental models. Carcinogenesis is a multi-step process requiring long-term exposure to the carcinogens. Typical developmental period for fiberinduced lung cancer in humans is $30-40$ years [23]. To mimic this long-term carcinogenic process, we have recently developed a chronic exposure model in which human lung bronchial and small airway epithelial cells, a major cellular target of human lung carcinogenesis, were continuously exposed to low-dose, physiologically relevant concentrations of SWCNT for a prolonged period of 6 months. Such chronic exposure resulted in irreversible malignant transformation and aggressive behaviors of the cells, activation of cancer-related canonical pathways, and induction of tumorigenesis in a mouse model $[24,25]$. A similar induction of aggressive/invasive phenotype was observed in mesothelial cells chronically exposed to SWCNT [26]. However, the fundamental mechanisms of SWCNT tumorigenesis are unclear at present.

Evolving research indicates that cancer stem cells (CSC) are a potential driving force of tumor initiation and progression due to their self-renewal and unlimited proliferative capacity $[27,28]$. The existence of CSC was reported in human cancers, including brain, breast, bone marrow, prostrate, colon, and lung [29,30]. The present study was undertaken to investigate whether chronic SWCNT exposure can induce lung CSC, and whether these cells possess tumorigenic activity. Our data demonstrated for the first time that SWCNT can interact with lung epithelial cells to induce CSC which have the propensity to form tumor spheres, indicating their neoplasticity and self-renewal capacity. Concurrent studies have shown that a small subpopulation of cells characterized as side population (SP) may be a source of CSC [30,31]. Here, we report the presence of this distinct SP subpopulation in chronic SWCNT-exposed lung cells that is enriched with CSC and shows more aggressive cancer phenotypes and tumor-initiating capability as compared to non-SP (non-CSC). These CSC also exhibit several stem cell phenotypes, including self-renewal and regeneration, and express a high level of pluripotent stem cell markers. Together, our study strengthens the earlier finding on potential SWCNT carcinogenicity and unveils a novel mechanism of SWCNT tumorigenesis toward the path of acquiring CSC traits, which may be shared by other engineered nanotubes and nanofibers.

\section{Results}

\section{CNT characterization and dosage calculation}

SWCNT were obtained from Carbon Nanotechnology (CNI, Houston, Texas) and were purified by acid treatment to remove metal contaminates. Elemental carbon analysis by NIOSH Manual of Analytical Methods (NMAM 5040) and metal analysis by nitric acid dissolution and inductive coupled plasma-atomic emission spectrometry (ICP-AES) showed that the purified SWCNT contained 99\% elemental carbon and less than $1 \%$ of contaminants. The metal residues were mostly iron $(\mathrm{Fe})$ at $0.23 \%$ by weight. The Brunauer Emmet Teller (BET) surface area, length (L), and width (W) of individual dry SWCNT were $400-1040 \mathrm{~m}^{2} / \mathrm{g}, 0.1-1 \mu \mathrm{m}(\mathrm{L})$, and 0.8-1.2 $\mathrm{nm}(\mathrm{W})$ (see Table 1 for summary). SWCNT were dispersed by acetone/sonication method as previously described $[16,24,32]$. The CNT doses used in the in vitro exposure studies were calculated based on in vivo $\mathrm{CNT}$ exposure 


\begin{tabular}{|c|c|c|}
\hline & SWCNT & Crocidolite asbestos \\
\hline Manufacturer & $\mathrm{CNI}$ & NIEH, Kalahari Desert \\
\hline Catalog reference & Unidym $^{T M}$ & CAS 12001-28-4 \\
\hline Synthesis & $\mathrm{HiPcO}$ & Natural \\
\hline Purification & Acid treatment & - \\
\hline BET surface area $\left(\mathrm{m}^{2} / \mathrm{g}\right)$ & $400-1040$ & 9.8 \\
\hline Dry mean length $(\mathrm{L})(\mu \mathrm{m})$ & $0.1-1$ & 210 \\
\hline Dry mean width $(\mathrm{W})(\mathrm{nm})$ & $0.8-1.2$ & 10 \\
\hline$\%$ carbon (w/w) & $>99 \%$ & - \\
\hline \multicolumn{3}{|l|}{$\%$ metal impurity (w/w) } \\
\hline $\mathrm{Fe}$ & $0.23 \%$ & $31.8 \%$ \\
\hline $\mathrm{SiO}_{2}$ & - & $50.9 \%$ \\
\hline Other trace metals & Not detectable & $6.2 \%$ \\
\hline
\end{tabular}

data normalized to alveolar surface area in mice. For example, the lowest dose which induced positive in vivo biological response was $10 \mu \mathrm{g} /$ mouse lung $(0.5 \mathrm{mg} / \mathrm{kg}$ body weight) $[8,9]$. Dividing this dose by the average alveolar surface area in mice $\left(\sim 500 \mathrm{~cm}^{2}\right)$ [33] indicates the in vitro surface area dose of $0.02 \mu \mathrm{g} / \mathrm{cm}^{2}$, which is equivalent to a human lung burden for 8 hours/day over a month at $400 \mu \mathrm{g} / \mathrm{m}^{3}$ (high CNT level reported in a research facility) [34] or about 3 years at $10 \mu \mathrm{g} / \mathrm{m}^{3}$ (average CNT level in U.S. facilities) [35].

\section{Chronic SWCNT exposure induces CSC-like cells}

Subconfluent cultures of human small airway epithelial cells (SAEC) and bronchial BEAS-2B epithelial cells were continuously exposed to a low-dose physiologically relevant concentration of SWCNT at $0.02 \mu \mathrm{g} / \mathrm{cm}^{2}$ in culture and passaged weekly for a period of 6 months. The cells were cultured in normal medium without SWCNT for at least ten passages prior to further experiments. These chronic SWCNT-exposed cells were previously shown by our group to possess irreversible malignant transforming properties, altered cancer-related canonical pathways, and tumor forming activity in mice $[24,25]$. The ability to self-renew and generate different differentiated progeny is fundamental properties of CSC. A key characteristic of CSC is the formation of tumor spheres in stem-cell selective condition of serum-free media and non-adherence $[31,36]$. To first assess the existence of CSC in SWCNT-transformed cells, chronic SWCNT-exposed bronchial epithelial cells (designated as BSW) and passage-matched control (BC) cells were evaluated by the tumor sphere formation assay as well as soft-agar colony formation assay which is the most stringent indicator of malignant transformation [37]. Chronic SWCNT-exposed BSW cells formed large $(>50 \mu \mathrm{m})$ colonies and tumor spheres, similarly to the positive control non-small cell lung cancer $\mathrm{H} 460$ cells, whereas the passage control $\mathrm{BC}$ cells showed minimal number of small colonies and spheres (Figure 1A and B), indicating malignant transformation, neoplasticity, and self-renewal property of SWCNT-exposed BSW cells, comparable to lung cancer $\mathrm{H} 460$ cells.

Various adult stem cells and CSC derived from solid tumors and cancer cell lines have been previously identified by an SP phenotype with enriched stem cell activity $[30,31,38]$. A small subpopulation of SP cells is characterized by their distinct low Hoechst 33342 dye staining, attributable to their high expression of ABCG2 transporter. To assess the SP phenotype of our cell systems, malignant transformed BSW and lung cancer $\mathrm{H} 460$ cells were stained with $5 \mu \mathrm{g} / \mathrm{mL}$ of Hoechst 33342 in the presence or absence of $10 \mu \mathrm{M}$ fumitremorgin C (FTC), a specific inhibitor of ABCG2 transporter. SP cells, which disappear in the presence of FTC, were identified and calculated as a proportion of the pool population ranging from approximately $15 \%$ in BSW and $\mathrm{H} 460$ cells to less than $1 \%$ in the passage-control BC cells (Figure 1C and E). To confirm the renewal or repopulation ability of the identified CSC, we extracted the cells from tumor spheres and SP subpopulation (designated as first-generation cells) and cultured them for 3 weeks under normal adherent conditions before they were reanalyzed. The cells that were derived from the firstgeneration of both BSW and H460 spheres and SP preserved the ability to form second-generation spheres and SP (Figure 1D and E).

To validate the existence of CSC and SP phenotypes and to rule out the potential effects of SV40 viral proteins as a result of BEAS-2B immortalization, we performed analysis of tumor spheres and SP in chronic SWCNT-exposed small airway epithelial cells (designated as SASW) compared with their passage-control (SAC) cells and positive control asbestos-exposed (SAAB) cells. Consistent with the earlier finding in BSW and H460 cells, SASW cells demonstrated tumor spheres and SP fraction comparable to $\mathrm{SAAB}$ cells that are greater than passage-control SAC cells (Figure 2A-D), thus supporting the generality of the observed CSC and SP phenotypes in SWCNTtransformed lung cells independent of their SV40 status. To our knowledge, this is the first demonstration of the induction of CSC by chronic low-dose exposure to SWCNT or any other nanomaterials.

Isolation and characterization of SWCNT-derived CSC cells Flow cytometry-based fluorescence-activated cell sorting (FACS) enables the isolation of SP from chronic SWCNTexposed cells and positive control lung cancer cells. SP and non-SP (NSP) cell sorting profiles of malignant transformed BSW and lung cancer $\mathrm{H} 460$ cells with more than $80 \%$ sorted purity are shown in Figure 3A. Sorted SP and 

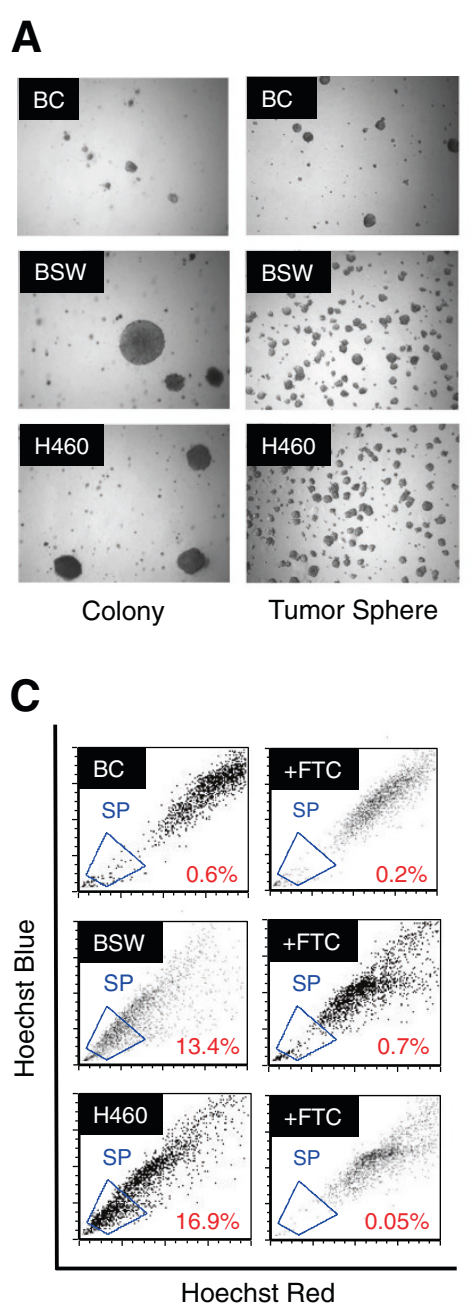

B
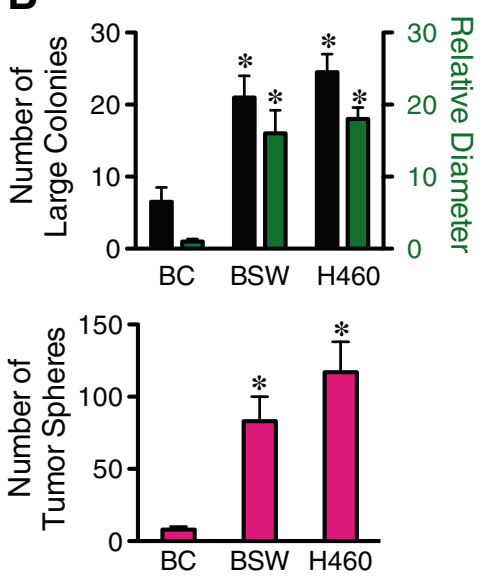

D

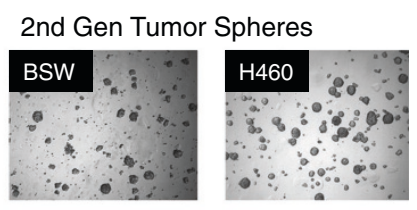

E

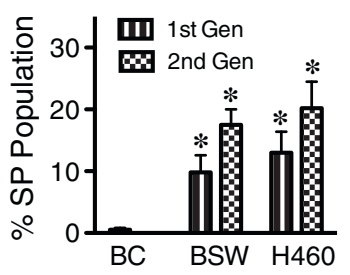

Figure 1 Chronic exposure to SWCNT induces malignant transformation and CSC formation in bronchial epithelial cells. (A) Analysis of colony formation (left) and tumor spheres (right) in passage control BC cells, chronic SWCNT-exposed BSW cells, and lung cancer H460 cells after two weeks of culture. (B) Quantitative analysis of colony (top) and tumor spheres (bottom). (C) Analysis of side population (SP) in BC, BSW, and H460 cells in the presence or absence of fumitremorgin c (FTC) using FACS. SP cells (box) are determined by their disappearance in the presence of FTC. (D, E) Analysis of second-generation tumor spheres (D) and SP (E). Data are mean \pm SD $(n=4) .{ }^{*} p<0.05$ vs. control BC cells.

NSP cells displayed different light-scattering properties under flow cytometric analysis. Forward-scattered light (FSC) measures mostly diffracted light and is proportional to cell size, whereas side-scattered light (SSC) measures mostly refracted light and is proportional to cell granularity or content [39]. Sorted SP cells derived from both BSW and H460 cells exhibited lower FSC and SSC compared to NSP cells (Figure 3B), suggesting that SP cells are smaller than NSP cells and have lower cytosolic content. The average cell size of SP and NSP cells as measured by Countess ${ }^{\circ}$ automated cell counter was $13.40 \pm 0.7 v s$. $16.05 \pm 0.90 \mu \mathrm{m}$ in BSW-SP and NSP cells, and $13.03 \pm$ 0.43 vs. $14.55 \pm 1.06 \mu \mathrm{m}$ in H460-SP and NSP cells, respectively. These results support the notion that sorted SP and NSP cells are not identical in cellular morphology and structure, and that SP and NSP cells may possess different cellular behaviors. Due to the high dynamics of CSC that are continuously undergoing cell differentiation in normal culture conditions, cells were freshly isolated prior to each experiment.

We next examined the neoplastic growth of SP and NSP cells in soft agar cultures. Figure 3 C shows that SP cells derived from both malignant transformed BSW and lung cancer H460 cells were proficient in colony formation, whereas NSP cells grew minimally. To further investigate whether SP cells are enriched with stem cell activity, we cultured the sorted cells under stem cell-selective conditions using tumor sphere formation assays. Figure 3D shows that SP cells formed faster and larger tumor spheres as compared to NSP cells, indicating the enrichment of CSC phenotype in the SP fraction derived from BSW and H460 cells. Having validated that SP cells possess CSC 
A
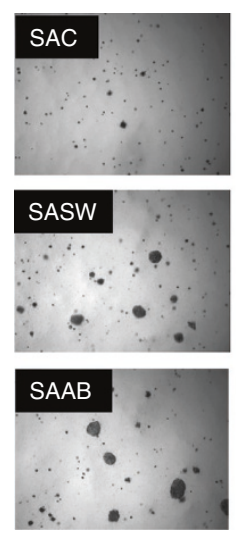

Colony
C
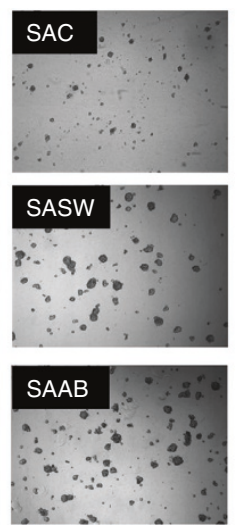

Tumor Sphere

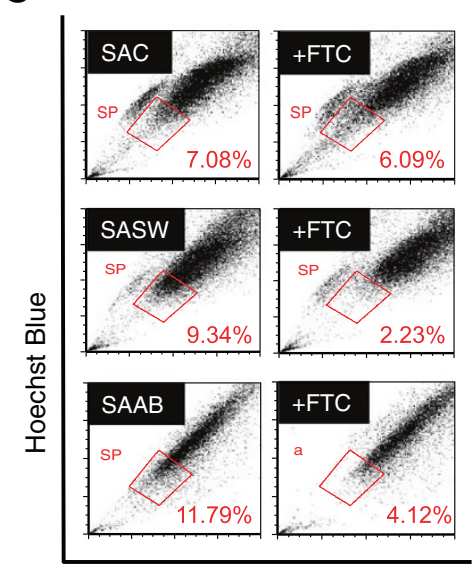

Hoechst Red
B

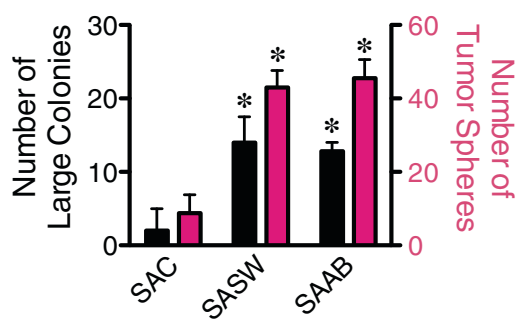

D

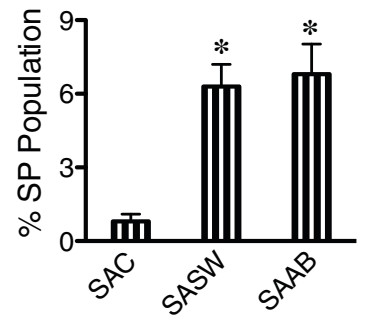

Figure 2 Chronic exposure to SWCNT induces malignant transformation and CSC formation in small airway epithelial cells. (A) Analysis of colony formation (left) and tumor spheres (right) in passage control SAC cells, chronic SWCNT- and asbestos-exposed SASW and SAAB cells after three weeks of culture. (B) Quantitative analysis of colony and tumor spheres. (C) Analysis of side population (SP) in SAC, SASW, and SAAB cells in the presence or absence of fumitremorgin C (FTC) using FACS. SP cells (box) are determined by their disappearance in the presence of FTC. (D) Quantitative analysis of SP subpopulation. Data are mean \pm SD $(n=4) .{ }^{*} p<0.05$ vs. control SAC cells.

properties, SP phenotype was subsequently used to isolate CSC cells from chronic SWCNT-exposed lung cells and lung cancer cells.

\section{Aggressive tumor phenotypes of SWCNT-derived CSC cells} CSC are known to contribute to the death resistance and aggressive behavior of human cancer cells [40]. We investigated the tumor-associated phenotypes of CNTderived CSC-like (SP) cells by first measuring their acquired apoptosis resistance to chemotherapy, which is a key characteristic of CSC [41]. Sorted SP and NSP cells derived from malignant transformed BSW and lung cancer $\mathrm{H} 460$ cells were treated with various chemotherapeutic agents, including cisplatin, doxorubicin, antimycin A and etoposide, and analyzed for apoptosis by Hoechst 33342 assay at 24 hours post-treatment. Cells having intensely condensed and/or fragmented nuclei were considered apoptotic. Figure 4A demonstrated the resistance of SP cells from both BSW and H460 cells to all chemotherapeutic agents tested $v s$. their matching NSP cells. We further compared their invasion and migration activities, which are key determinants of tumor progression [42] using Transwell $^{\circledR}$ invasion (inserts coated with $\mathrm{Matrigel}^{\odot}$ ) and migration (control inserts) assays. The SP cells derived from malignant transformed BSW and lung cancer H460 cells exhibited significantly higher invasion and migration rates than those of the NSP cells (Figure 4B). These results indicate the aggressive tumor phenotype of CSC-like (SP) cells derived from chronic SWCNT-exposed cells, comparable to that of the SP cells derived from lung cancer H460 cells.

\section{SWCNT-derived CSC cells induce tumor formation in vivo}

To test whether the CSC-like (SP) fraction is enriched with tumorigenic cells, the SP and NSP cells from malignant transformed BSW cells and lung cancer H460 cells were subcutaneously injected into NSG mice and monitored for tumor development. At the injection dose of $1 \times 10^{5}$ cells, tumor size (weight) and volume were higher in the SP cells derived from H460 cells but not from BSW cells (Table 2). No tumors were observed in mice injected with passage-control BC cells. As the number of cells is important in tumor initiation [30,31], we performed serial dilution of SP and NSP cells derived 

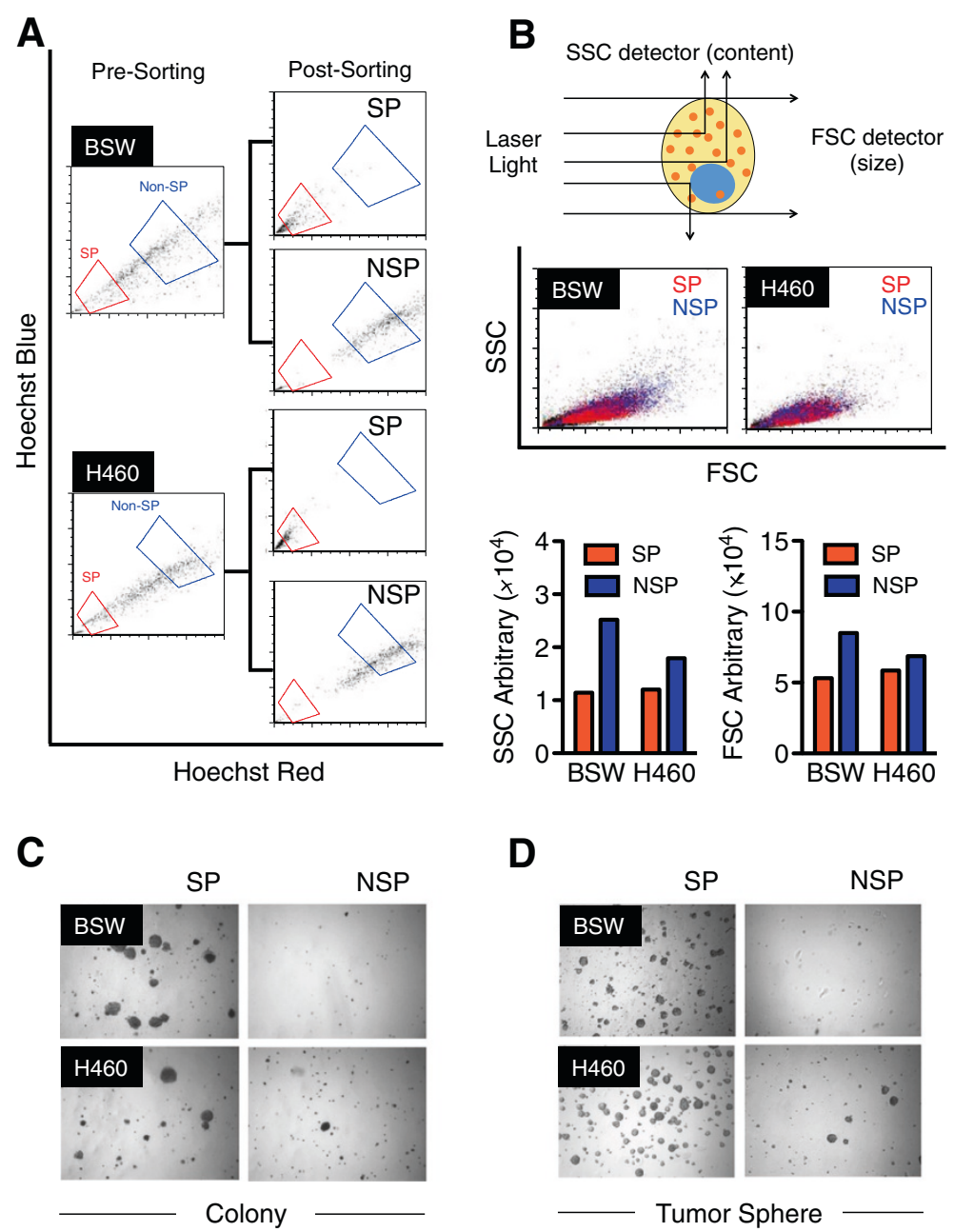

Figure 3 Isolation and characterization of CSC-like cells from SWCNT-exposed lung epithelial cells. (A) SP and non-SP (NSP) FACS sorting profiles of malignant transformed BSW and lung cancer $\mathrm{H} 460$ cells. Due to their highly dynamic nature of CSC, cells were freshly isolated prior to each experiment. (B) Light scattering properties of SP (red) and NSP (blue) cells derived from BSW and H460 cells as evaluated by flow cytometry. (C, D) Analysis of colony formation (C) and tumor spheres (D) in SP and NSP cells derived from BSW and H460 cells after two weeks of culture.

from malignant transformed BSW cells. As shown in Table 2, the SP cells from BSW (BSW-SP cells) were able to form tumors in mice with as little as $5 \times 10^{3}$ cells at 25-day latency period. Greater tumor incidence, size, and volume were observed with SP cells than NSP cells at these lower cell numbers. The growth kinetics of SP and NSP tumors from $\mathrm{H} 460$ at $1 \times 10^{5}$ (Figure 5A) and BSW at $5 \times 10^{3}$ (Figure 5B) further demonstrated the increased degree of tumor formation of SP cells. Representative SP and NSP tumors of BSW and H460 cells are shown in Figure 5C and D. Histological analysis of SP tumors from BSW showed classical cancer cell morphology including the condensation of heterochromatin and the presence of multinucleated cells, an indicator of mitotic dysfunction [43] (Figure 5F), similarly to those obtained from H460 (Figure 5E). These results demonstrate the tumorigenicity of SWCNT-induced
CSC-like (SP) cells and provide a mechanistic insight into the role of CSC in SWCNT tumorigenesis.

\section{Expression of putative stem cell markers in SWCNT- derived CSC cells}

CSC have phenotypic resemblance to normal stem cells. We thus evaluated the possible correlation of putative stem cell markers to CNT-derived CSC using human stem cell protein arrays, which detect several putative stem cell markers including Oct-3/4, Nanog, SOX2, E-cadherein, $\alpha$-fetoprotein, GATA-4, HNF-3 $\beta /$ FoxA2, PDX-1/IPF1, SOX17, Otx2, TP63/TP73L, goosecoid, snail, VEGF R2/KDR/Flk-1, and HCG. The result, which is shown in Figure 6A and is confirmed by Western blot analysis in Figure 6B, revealed the specific overexpression of Nanog, SOX2 and SOX17, and repression of E-cadherin in SP cells as compared to NSP cells. As 

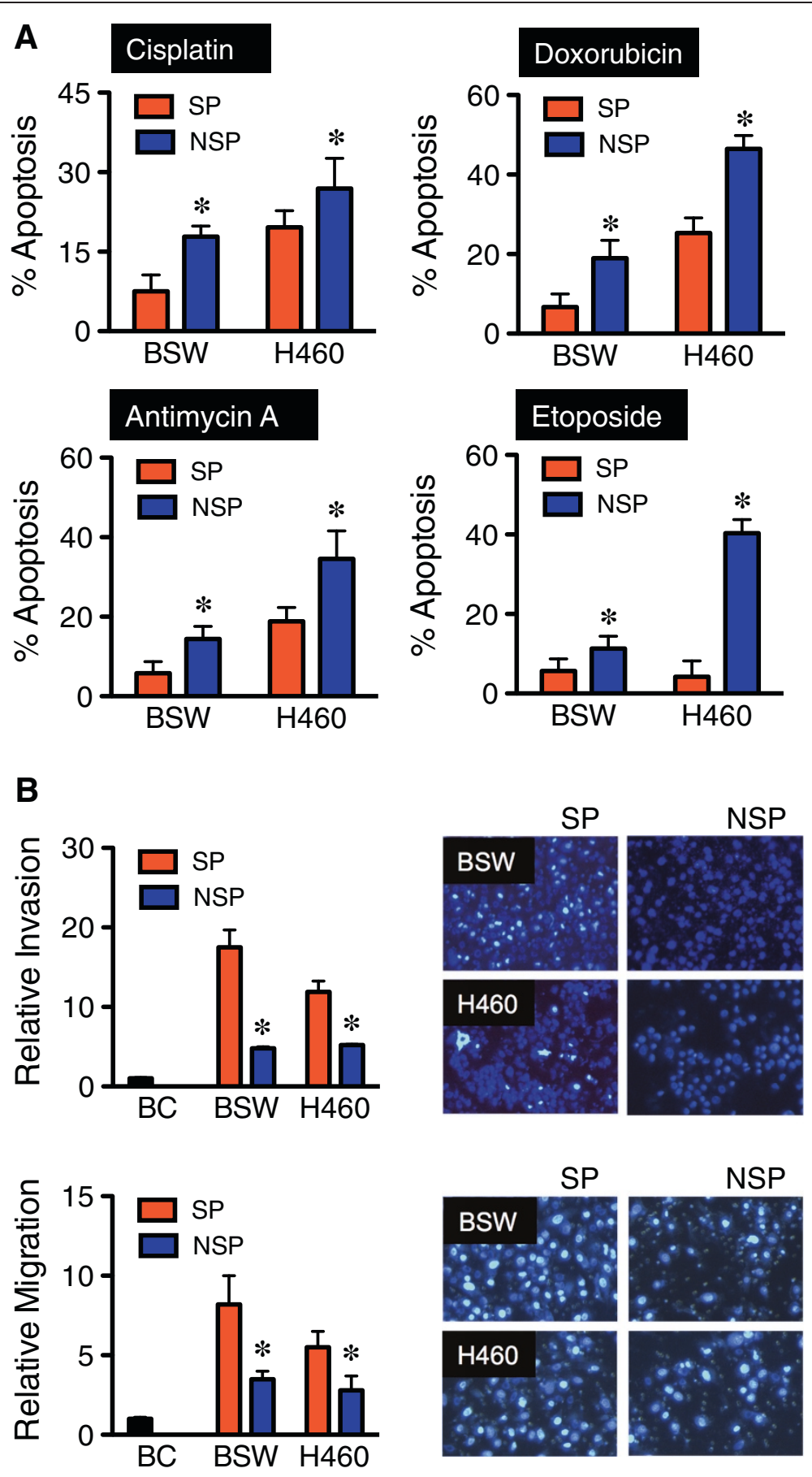

Figure 4 Aggressive tumor phenotypes of CSC-like cells derived from SWCNT-exposed lung epithelial cells. (A) Acquired apoptosis resistance of SP cells derived from malignant transformed BSW and lung cancer H460 cells to chemotherapy cisplatin (100 $\mu$ M), doxorubicin $(1 \mu \mathrm{M})$, antimycin $\mathrm{A}(30 \mu \mathrm{M})$, and etoposide $(500 \mathrm{nM})$, compared to their respective non-SP (NSP) cells, as analyzed by Hoechst 33342 assay at 24 hours post-treatment. (B) Cell invasion (top) and migration (bottom) assays of SP and NSP cells derived from BSW and H460 cells, and the passage control BC cells, at 48 hours after incubation. Plots are relative invasion and migration level normalized to passage control BC cells. Representative fluorescence micrographs of invading and migrating cells are shown (right). Data are means \pm SD $(n=4)$. ${ }^{*} p<0.05$ vs. SP cells. 
Table 2 CSC-like (SP) cells are enriched with tumorigenic cells

\begin{tabular}{|c|c|c|c|c|c|c|}
\hline \multirow[t]{2}{*}{ Cell types } & \multirow[t]{2}{*}{ Cell number } & \multirow[t]{2}{*}{ Incidence } & \multirow[t]{2}{*}{ Latency (day) } & \multirow[t]{2}{*}{ Necropsy (day) } & \multicolumn{2}{|c|}{ Tumor } \\
\hline & & & & & Volume $\left(\mathrm{mm}^{3}\right)$ & Weight (g) \\
\hline \multicolumn{7}{|l|}{ H460 } \\
\hline SP & $1 \times 10^{5}$ & $3 / 3$ & 12 & 21 & $506 \pm 190$ & $0.61 \pm 0.28$ \\
\hline NSP & $1 \times 10^{5}$ & $3 / 3$ & 14 & 21 & $202 \pm 74$ & $0.33 \pm 0.13$ \\
\hline \multicolumn{7}{|l|}{ BSW } \\
\hline SP & $1 \times 10^{5}$ & $3 / 3$ & 14 & 21 & $170 \pm 155$ & $0.34 \pm 0.21$ \\
\hline NSP & $1 \times 10^{5}$ & $3 / 3$ & 14 & 21 & $145 \pm 21$ & $0.34 \pm 0.24$ \\
\hline \multicolumn{7}{|l|}{ BSW } \\
\hline SP & $5 \times 10^{4}$ & $2 / 2$ & 18 & 28 & $340 \pm 18$ & $0.53 \pm 0.47$ \\
\hline NSP & $5 \times 10^{4}$ & $1 / 2$ & - & 28 & $140 \pm 199$ & $0.20 \pm 0.28$ \\
\hline \multicolumn{7}{|l|}{ BSW } \\
\hline SP & $5 \times 10^{3}$ & $4 / 4$ & 25 & 35 & $823 \pm 556$ & $1.04 \pm 0.64$ \\
\hline NSP & $5 \times 10^{3}$ & $2 / 4$ & - & 35 & $198 \pm 376$ & $0.43 \pm 0.51$ \\
\hline $\mathrm{BC}$ & $1 \times 10^{5}$ & $0 / 2$ & - & - & - & - \\
\hline
\end{tabular}

Data are means \pm SD $(n=2,3$ or 4$)$.

putative stem cell markers typically determine selfrenewal efficiency and maintenance of stem cells, this data strengthens the stem properties of CSC-like (SP) cells in chronic SWCNT-exposed lung cell population.

Stem cell surface markers have provided powerful tools in stem cell research, i.e., in isolation and characterization of stem cell population and differentiation. As CSC are known to be important in the initiation and progression of cancers, stem cell markers induced by SWCNT might potentially be used for risk assessment and early detection of SWCNT carcinogenic potential. To identify the candidate CSC markers, SP and NSP cells from malignant transformed BSW cells were analyzed for stem cell surface markers CD24, CD44, and CD133 [44,45] in comparison to their passage-control BC cells. A significant decrease in CD24 expression was observed in SP and NSP cells as compared to $\mathrm{BC}$ cells with the rank order of expression being $\mathrm{BC}>\mathrm{NSP}>\mathrm{SP}$ (Figure 6C). In contrast, CD133 expression was highest in the SP cells followed by NSP and $\mathrm{BC}$ cells $(\mathrm{SP}>\mathrm{NSP}>\mathrm{BC}$ ) (Figure 6D). No significant difference in CD44 level was observed in SP and NSP cells, although the level is elevated in BC cells. The correlation between CD24 $4^{\text {low }}$ and CD $133^{\text {high }}$ and the tumorigenic activity of SP cells suggests the potential utility of these stem cell markers as candidate biomarkers for the detection of SWCNT tumorigenesis.

Role of tumor suppressor p53 in SWCNT-derived CSC cells We earlier reported that tumor suppressor p53 mediated the acquired apoptosis resistance of chronic CNT-exposed lung cells, which could be a potential mechanism underlying SWCNT tumorigenesis [24]. However, supporting evidence is lacking. Malignant transformed BSW cells were transfected with p53 or control GFP plasmid, then subcutaneously injected into NSG mice and monitored for tumor formation. At the injection dose of $1 \times 10^{5}$ cells, p53-overexpressing BSW cells showed a remarkably lower incidence of tumor formation as compared to wild-type cells (Figure 7A). To investigate whether p53 could possibly regulate SWCNT-derived CSC, p53-overexpressing cells were evaluated for CSC features of tumor sphere formation and SP subpopulation. Figure 7B shows that p53 restored expression substantially inhibited tumor spheres and SP, indicating the role of p53 in CSC regulation. We further observed the inhibitory effect of p53 on aggressive cancer phenotype, e.g. cell invasion and migration (Figure 7C). Importantly, p53-overexpressing cells were shown to express CD24 ${ }^{\text {high }}$ and $\mathrm{CD} 133^{\text {low }}$ stem cell surface markers (Figure 7D). These results are in good agreement with the observed lower fraction of CSC and indicate the tumor suppressing activity of p53 in SWCNT tumorigenesis in part through CSC inhibition.

\section{Discussion}

Lung cancer is the leading cause of cancer death, and environmental and occupational exposure is the major cause of most cases [46,47]. The objective of this study was to address human lung cancer risks associated with chronic pulmonary exposure to SWCNT through the fundamental understanding of cellular and molecular processes leading to carcinogenesis. Long-term exposure to workplace-relevant doses of SWCNT, one of the major forms of engineered CNT, were previously shown by our group to induce irreversible malignant transformation and alter cancer-related canonical pathways of lung epithelial cells [24,25]. However, detailed understandings of the pathological process are lacking. Accumulating evidence suggests that various solid tumors including brain, breast, 

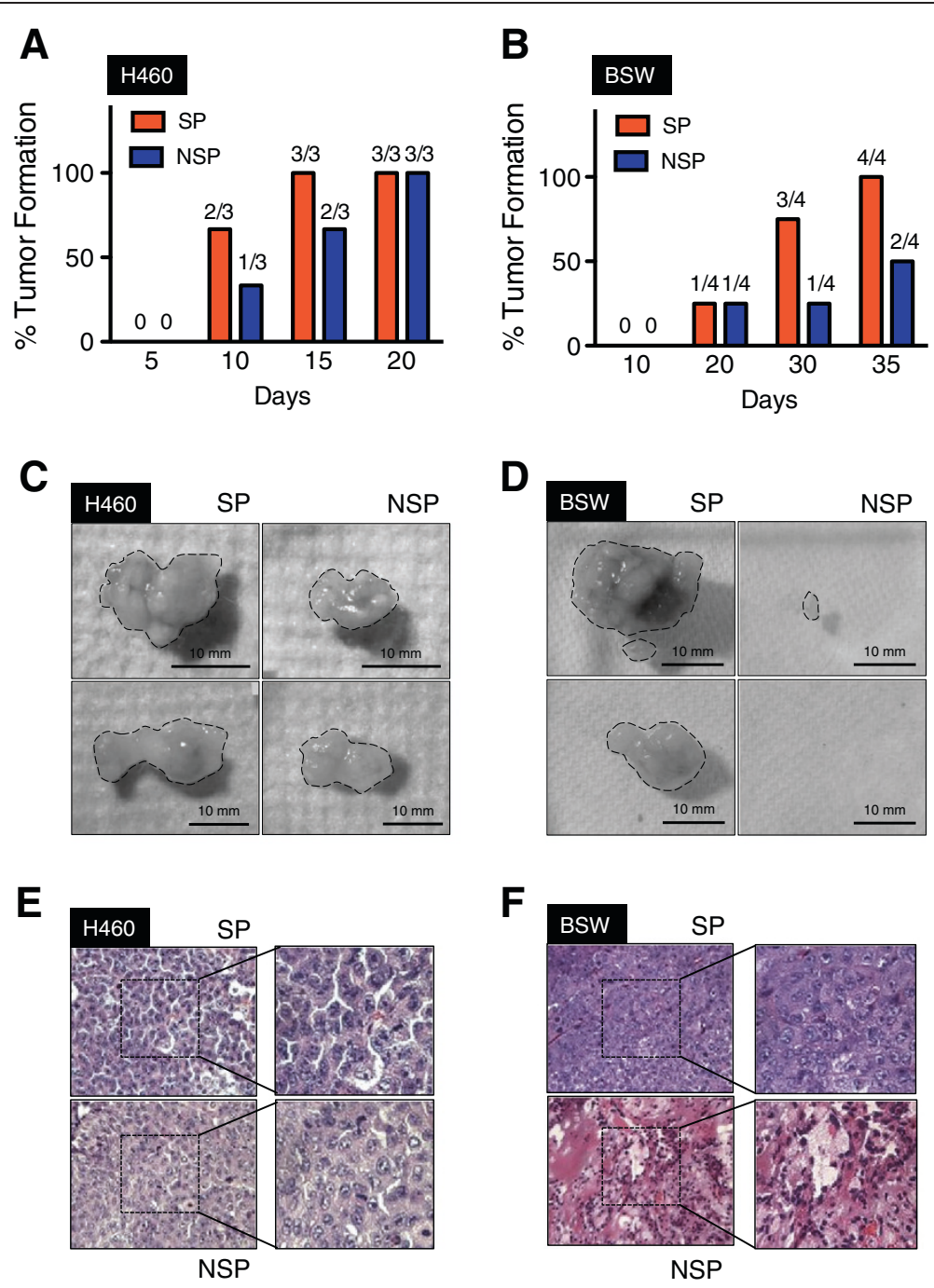

Figure 5 Tumorigenicity of SWCNT-induced CSC-like cells. (A, B) Growth kinetics of SP and non-SP (NSP) tumors derived from lung cancer H460 (A) and malignant transformed BSW (B) cells. (C, D) Representative SP (left) and NSP (right) tumors derived from H460 (C) and BSW (D) cells. $(\mathbf{E}, \mathbf{F})$ Representative H\&E micrographs of SP and NSP tissue samples derived from H460 (E) and BSW (F) cells. Condensation of heterochromatin and multi-nucleated cells are evident in the tissue samples from SP and NSP derived from H460, and SP derived from BSW cells.

bone marrow, prostrate, colon, and lung contain a rare population of CSC that have a high repopulation capacity and are a major driving force of tumor initiation and progression $[29,30,48]$. Hence, identifying these CSC provides a fundamental understanding of the carcinogenic process, particularly at the early developmental stage. We investigated whether chronic SWCNT exposure can induce lung CSC and studied their role in tumorigenesis. SWCNT were a focus of this study because they are generally more toxic than MWCNT as indicated by their cytotoxicity [49-51] and fibrogenicity [7,52]. Non-small cell lung cancer $\mathrm{H} 460$ cells were used in parallel and served as a positive control. Our results demonstrated for the first time the existence of CSC subpopulation within all clones of chronic SWCNT-exposed lung cells. These cells have the propensity to form tumor spheres under serum-starved, non-adherent conditions (Figures 1 and 2), similar to that observed in non-small cell lung cancer cells and chronic asbestos-exposed lung cells. We also demonstrated the presence of side population (SP), the subpopulation found in various solid tumors with stem cell properties, in the SWCNT-transformed cells. The proportion of SP population correlated well with the tumor sphere-forming capability of CSC. These results suggest that SWCNT can directly interact with lung epithelial cells to initiate CSC formation.

To substantiate the functional role of CSC in SWCNT tumorigenesis, we further characterized and isolated SWCNT-transformed cells into two subgroups based on their SP phenotype as CSC (SP) and non-CSC (non-SP 

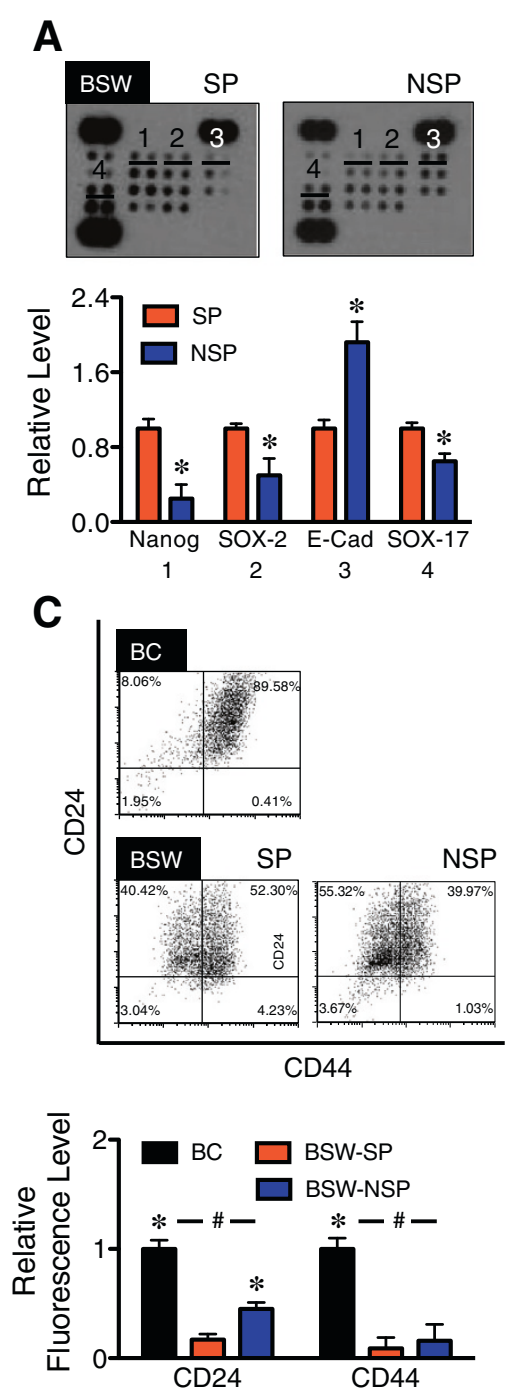

B
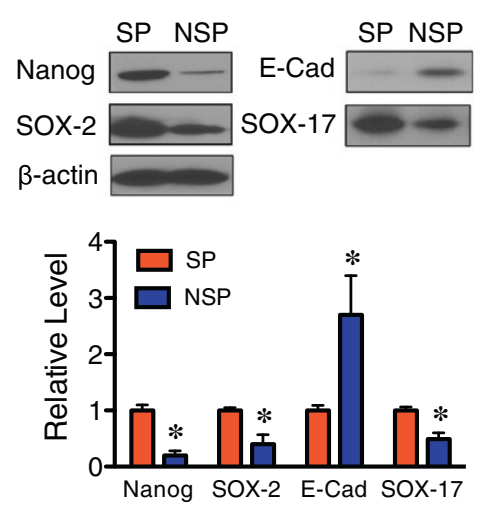

D
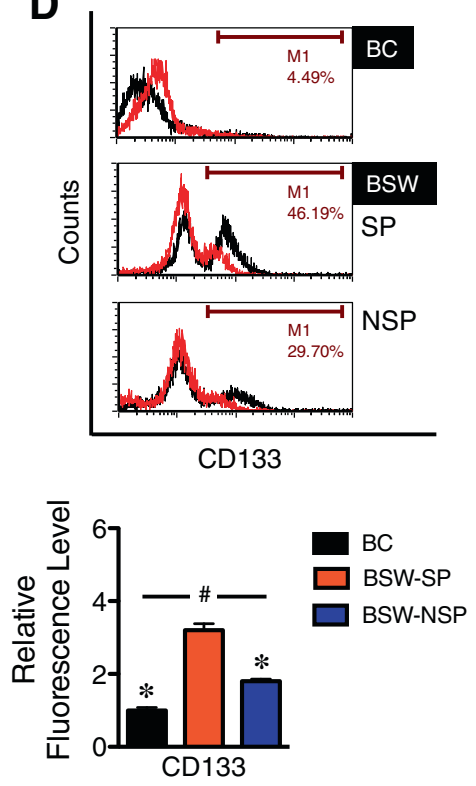

Figure 6 Expression of stem cell markers in CSC-like cells derived from SWCNT-exposed lung epithelial cells. (A) Analysis of pluripotent stem cell markers in SP and non-SP (NSP) derived from malignant transformed BSW cells using the Proteome Profiler ${ }^{\mathrm{TM}}$ Array (R\&D Systems). Pixel densities of remarkable stem cell markers (1) Nanog, (2) SOX-2, (3) E-cadherin (E-Cad), and (4) SOX-17 from the arrays are shown. (B) Western blot analysis of Nanog, SOX-2, E-cadherin, and SOX-17 comparing SP and NSP cells derived from BSW cells. (C, D) Analysis of stem cell surface markers CD24, CD44, and CD133 in SP and NSP cells derived from BSW cells using flow cytometry, comparing with the passage control BC cells. Plots are relative fluorescence level normalized to control BC cells. Data are means \pm SD $(n=3) .{ }^{*} p<0.05$ vs. SP cells, ${ }^{\#} p<0.05$ vs. BC cells.

or NSP). The SP phenotype was used because of their demonstrated CSC properties and their reliability of isolation by fluorescence-activated cell sorting (Figure 3). Carcinogenesis involves several cellular processes that contribute to the aggressive behaviors of cells including abnormal growth, increased migration and invasion, evasion of apoptosis, and angiogenesis [53,54]. CSC are known to contribute to the aggressive behaviors of human cancer cells [41,55]. SWCNT-derived CSC acquired apoptosis-resistant and invasive phenotypes as compared to non-CSC (Figure 4). Acquired apoptosis resistance is a hallmark of cancer cells [53]. It promotes cell survival during the carcinogenic process against endogenous anti-growth signals and immune cell killing mechanisms [56]. Whereas, increased cell migration and invasion are crucial to metastasis and are key determinants of tumor progression [42,57]. The results of this study demonstrated the aggressiveness of SWCNTderived CSC and their ability to evade apoptosis, consistent with the findings observed in CSC derived from solid tumors.

CSC possess high tumorigenic potential [30,31,48]. We found that SWCNT-derived CSC, when injected into mice, have a high tumor-initiating capability as compared to non-CSC (Figure 5). A small number of CSC (e.g. $5 \times 10^{3}$ cells) can induce tumors in mice, whereas 


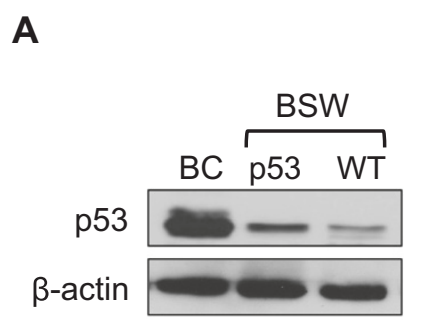

B

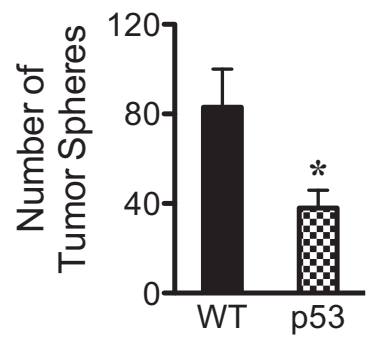

C

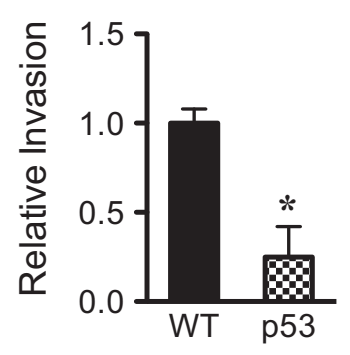

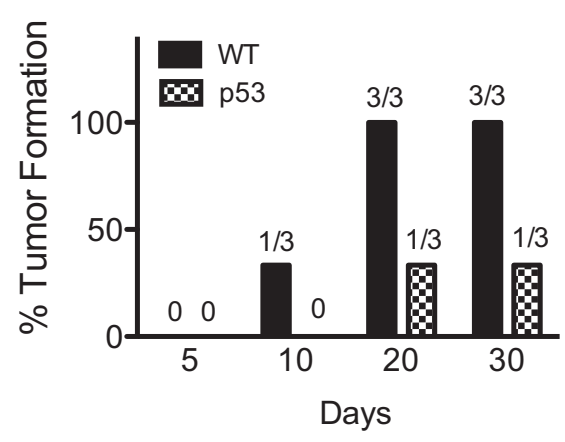
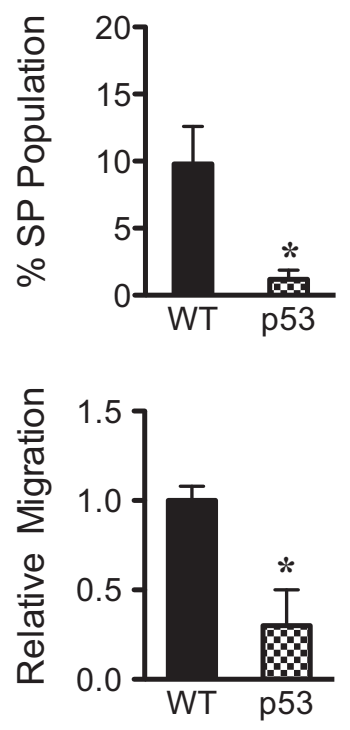

D

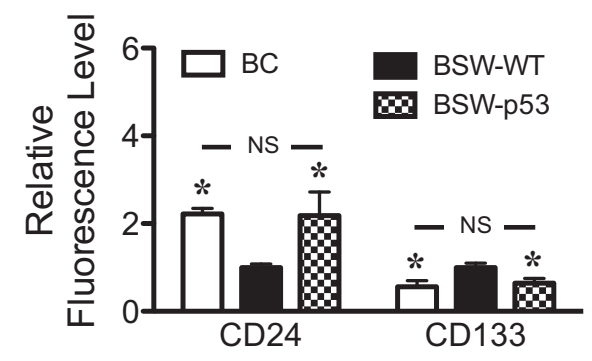

Figure 7 p53 regulates CSC-like cells from SWCNT-exposed lung epithelial cells. (A) Western blot analysis of p53 protein (left) and tumor growth kinetics (right) of wild-type (WT) and p53-overexpressed BSW tumors. (B) Quantitative analysis of tumor spheres (left) and side population (right) in WT and p53-overexpressed BSW cells. (C) Cell invasion (left) and migration (right) assays of WT and p53-overexpressed BSW cells. Plots are relative invasion and migration level normalized to WT cells. (D) Analysis of stem cell surface markers CD24 and CD133 in WT and p53-overexpressed BSW cells using flow cytometry. Plots are relative fluorescence level normalized to WT cells. Data are means \pm SD $(n=3)$. ${ }^{*} p<0.05$ vs. WT cells. NS, not significant vs. BC cells.

non-CSC failed to form tumors in the majority of mice. The presence of a small number of CSC in a large population of non-CSC substantiated the role of CSC as tumor-initiating cells. This is significant because the early stage of carcinogenesis will most likely depend on these tumor-initiating cells.

Our stem cell protein array studies indicate an aberrant expression of several stem cell markers, notably Nanog,
SOX2, SOX17, and E-cadherin, in CNT-derived CSC (Figure 6). Hyperactivation of Nanog has previously been shown to promote CSC phenotypes in colon and prostate cancer cells and confer their resistance to apoptosis [58,59]. In breast cancer cells, SOX17 is distinctly upregulated in CSC-like (SP) cells in conjunction with the activation of $\mathrm{Wnt} / \beta$-catenin signaling pathway [29]. The role of SOX2 in CSC was investigated by 
several studies. For example, SOX2 overexpression was found to be critical in maintaining the antiapoptotic activity and tumorigenicity of lung CSC, possibly through the upregulation of oncogenes such as c-Myc, Wnt1, Wnt2, and Notch1 [60,61]. Meanwhile, repression of E-cadherin induces epithelial-mesenchymal transition (EMT), the process that is known to involve CSC acquisition in various cancers including lung cancer [62]. Altogether, our studies identify the stem properties of SWCNT-derived CSC and suggest the potential mechanisms that drive CSC acquisition in chronic SWCNTexposed lung cells.

Stem cell surface markers are powerful tool for characterization and isolation of normal and cancer stem cells. Having demonstrated that SWCNT-induced CSC are crucial to tumor initiation (Figure 5), stem cell surface markers induced by SWCNT could possibly be used for risk assessment of SWCNT carcinogenicity and early detection of SWCNT-induced tumorigenesis. We analyzed surface expression of key biomarkers CD24, CD44, and CD133 in CNT-derived CSC in comparison to non-CSC and non-CNT-exposed control cells. Our results showed the correlation between $\mathrm{CD} 24^{\text {low }}$ and $\mathrm{CD} 133^{\text {high }}$ and the tumor-initiating capability of the cells (Figure 6). $\mathrm{CD} 24^{\text {low }}$ is often used in conjunction with $\mathrm{CD} 44^{\text {high }}$ to identify CSC from breast tumors [63]. However, CNTderived CSC exhibited a low level of CD44 expression. Our results are in good agreement with a previous report showing $\mathrm{CD} 24^{\text {low }}$ and variable levels of $\mathrm{CD} 44$ ranging from high to undetectable in lung CSC [62]. The role of CD133, also known as AC133 or prominin-1, has been reported in lung cancer. CD133-positive subpopulation derived from lung cancer cell lines and patient-derived primary tumors were shown to possess biological features of CSC, including self-renewal and tumor-initiating capabilities $[64,65]$. In addition, the clinical importance of CD133 was recently shown to correlate with the pathological stage and prognosis of NSCLC patients [45]. With regards to its regulation, it was suggested that CD133 induction was mediated through Oct $3 / 4$ and SOX2 under the tumor microenvironment of hypoxia [66]. We also observed a striking upregulation of SOX2 in SWCNTderived CSC (Figure 6), suggesting the possible mechanism of CD133 induction in these cells.

Most human cancers have a tumor suppressor p53 inactivation [67]. Likewise, our results indicate an important role of p53 in SWCNT tumorigenesis. Chronic SWCNT-exposed BSW cells showed a substantially lower p53 level compared to their passage control cells. Restored expression of p53 to BSW cells results in tumor inhibition, which correlates well with the observed lower CSC fraction (Figure 7). Such restored expression has profound reversal effects on the aggressive cancer phenotypes and stem cell surface markers. These results support the notion that p53 suppresses SWCNT tumorigenesis in part through CSC inhibition and validate the findings that stem cell markers $\mathrm{CD} 24^{\text {low }}$ and $\mathrm{CD} 133^{\text {high }}$ are closely associated with SWCNT tumorigenesis.

In conclusion, we presented new evidence supporting the role of CSC in SWCNT tumorigenesis. Chronic exposure of human lung epithelial cells to SWCNT induces CSC with stem properties including the ability to self-renew and form tumor spheres in non-adhering conditions. These cells also possess aggressive cancer phenotypes and are tumorigenic in a mouse model. A schematic summary of our findings is shown in Figure 8. To our knowledge, this is the first demonstration of CSC induced by SWCNT and its role in tumorigenesis. This study supports the prudent adoption of prevention strategies and implementation of exposure control for SWCNT. Although the precise mechanisms underlying CSC acquisition remain to be further elucidated, tumor suppressor p53 in part plays a role. Furthermore, the hyperactivation of Nanog, SOX2 and SOX17, as well as the repression of E-cadherin seem to be involved. The results of this study also suggest the potential utility of stem cell surface markers $\mathrm{CD} 24^{\text {low }}$ and $\mathrm{CD} 133^{\text {high }}$ for early detection of SWCNT tumorigenesis. The CSC model and biomarkers described in this study may be useful in other carcinogenesis studies.

\section{Materials and methods \\ SWCNT characterization and preparation}

SWCNT were obtained from Carbon Nanotechnology (CNI, Houston, Texas) and were purified by acid treatment to remove metal contaminates. Elemental carbon analysis was performed by NIOSH Manual of Analytical Methods (NMAM 5040), whereas trace metal analysis was performed by nitric acid dissolution and inductive coupled plasma-atomic emission spectrometry (ICP-AES, NMAM 7300). The specific surface area was measured at $-196^{\circ} \mathrm{C}$ by the nitrogen absorption-desorption technique (Brunauer Emmet Teller method, BET) using a SA3100 Surface Area and Pore Size Analyzer (Beckman Coulter, Fullerton, CA). The diameter and length distribution of the SWCNT were measured by field emission scanning electron microscopy. SWCNT were dispersed by acetone/ sonication method $[16,24,32]$ or by using Survanta ${ }^{\circ}$ as previously described [25]. For acetone/sonication method, SWCNT were treated with acetone and placed in an ultrasonic bath for $24 \mathrm{~h}$. The dispersed SWCNT were then filtered from the solution using a $20-\mu \mathrm{m}$ nylon mesh screen followed by a $0.2-\mu \mathrm{m}$ polytetrafluoroethylene filter, which had been weighed prior to use. After filter collection, the dispersed SWCNT were washed thoroughly with distilled water, weighted, and suspended in phosphate-buffered saline with 2-3 minute sonication (Sonic Vibra Cell Sonicator, Sonic \& Material 


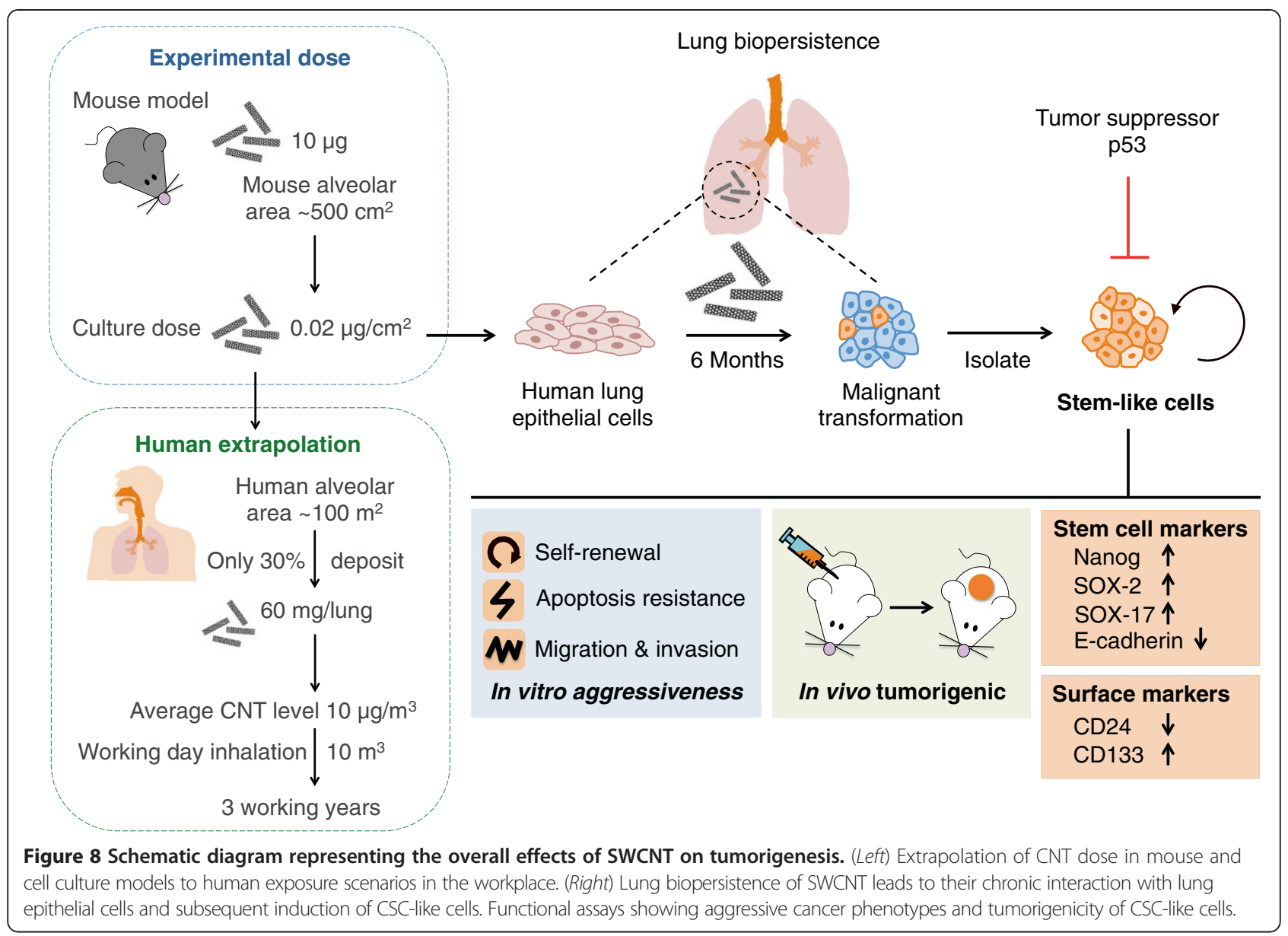

Inc, Newtown, CT, USA). For Survanta ${ }^{\circledR}$ dispersion, $1 \mathrm{mg}$ of SWCNT were dispersed in $1 \mathrm{~mL}$ of phosphate-buffer saline (PBS) containing $150 \mu \mathrm{g} / \mathrm{mL}$ of Survanta ${ }^{\circledR}$ (Abbott Laboratories, Abbott Park, IL) using light sonication and were diluted in culture medium to obtain the desired concentration.

\section{Chemicals and reagents}

Crocidolite asbestos (CAS\# 12001-28-4) was obtained from the National Institute of Environmental Health Sciences (Research Triangle Park, NC). Hoechst 33342, cis-diamminedichloroplatinum II (cisplatin), etoposide, antimycin A, and antibody against -actin were obtained from Sigma-Aldrich (St. Louis, MO). Doxorubicin was obtained from EMD Biosciences (La Jolla, CA). Human pluripotent stem cell array was obtained from R\&D Systems (Minneapolis, MN). Antibodies against Nanog, E-cadherin, and peroxidase-labeled secondary antibody were obtained from Cell Signaling Technology (Boston, MA). Antibodies against SOX2 and SOX17 were obtained from Millipore (Billerica, MA). Antibody against p53 was obtained from Santa Cruz Biotechnology (Santa Cruz, CA). Fluorochrome-conjugated antibodies against human
CD24, CD44, and CD133 were obtained from Miltenyi Biotec (Auburn, CA).

\section{Cell culture}

Primary human small airway epithelial cells (SAECs) immortalized with hTERT were kindly provided by Dr. Hei (Columbia University, NY) [68]. SAECs were cultured in SABM medium supplemented with Clonetics SAGM SingleQuots (Lonza, Walkersville, MD) which contain $0.4 \% \mathrm{v} / \mathrm{v}$ bovine pituitary extract, $0.1 \%$ insulin, $0.1 \%$ hydrocortisone, $0.1 \%$ retinoic acid, $1 \%$ bovine serum albumin, $0.1 \%$ transferrin, $0.1 \%$ triiodothyronine, $0.1 \%$ epinephrine, $0.1 \%$ human epidermal growth factor and $0.1 \%$ gentamicin. Human bronchial epithelial BEAS-2B cells were obtained from American Type Culture Collection (ATCC; Manassas, VA). They were cultured in Dulbecco's modified Eagle medium (DMEM) supplemented with $5 \%$ fetal bovine serum (FBS), 2 mM L-glutamine, 100 units $/ \mathrm{mL}$ penicillin and $100 \mu \mathrm{g} / \mathrm{mL}$ streptomycin. Non-small lung cancer cell (NSCLC)-H460 cells were obtained from American Type Culture Collection (Manassas, VA) and were cultured in RPMI 1640 medium supplemented with 5\% FBS, 2 mM L-glutamine, and 100 units/ 
$\mathrm{mL}$ penicillin/streptomycin. All cells were maintained in a humidified atmosphere of $5 \% \mathrm{CO}_{2}$ at $37^{\circ} \mathrm{C}$.

\section{Plasmid and transfection}

p53 and control GFP plasmids were obtained from Invitrogen (Carlsbad, CA). Cells were transfected with p53 or GFP plasmid by nucleofection using Nucleofector ${ }^{\odot}$ (Amexa Biosystems, Cologne, Germany), according to the manufacturer's instructions. Briefly, cells were suspended in $100 \mu \mathrm{L}$ of nucleofection solution with $2 \mu \mathrm{g}$ of plasmid and nucleofected using the device program T020. The cells were then resuspended in $500 \mu \mathrm{L}$ of complete medium and seeded in $60-\mathrm{mm}$ cell culture dishes. Cells were allowed to recover for 48 hours before each experiment. The efficiency of transfection was determined by using a green fluorescent protein reporter plasmid and was found to be $\sim 80 \%$.

\section{Chronic SWCNT exposure and derivation of SWCNT-transformed cells}

Lung epithelial BEAS-2B and SAEC cells were continuously exposed to low-dose SWCNT (surface area dose of $0.02 \mu \mathrm{g} / \mathrm{cm}^{2}$ or concentration dose of $0.1 \mu \mathrm{g} / \mathrm{mL}$ ) in culture for 6 months. The cells were passaged weekly at preconfluent densities using a solution containing 0.05\% trypsin and $0.5 \mathrm{mM}$ EDTA (Invitrogen, Carlsbad, CA). SWCNT-exposed BEAS-2B cells were designated as BSW cells, whereas SWCNT-exposed SAEC cells were designated as SASW cells. Parallel cultures grown in SWCNTfree medium with the same background level of dispersant provided passage-matched controls and were designated as BC and SAC cells for the cells originated from BEAS2B and SAEC cells, respectively. After 6 months of exposure, the cells were cultured in normal complete medium, and their cancer and CSC phenotypes were assessed as described below. Human non-small cell lung cancer H460 cells were used as a positive control in the studies.

\section{Soft agar colony formation assay}

Soft agar assay was performed as previously described with minor modifications [69]. Passage-control BC and SAC cells, and chronic SWCNT-exposed BASW and SASW cells $\left(3 \times 10^{4}\right.$ cells $)$ were mixed with culture medium containing $0.5 \%$ agar to a final agar concentration of $0.33 \%$. Cell suspensions were immediately plated onto dishes coated with $0.5 \%$ agar in culture medium. Colonies were examined under a light microscope after 2 weeks of culture.

\section{Tumor sphere assay}

Tumor sphere assay was performed under non-adherent and serum-free conditions as previously described as stem cell-selective conditions [31,36]. Briefly, cells were resuspended in $0.8 \%$ methylcellulose $(\mathrm{MC})$-based serum-free medium (Stem Cell Technologies, Vancouver, Canada) supplemented with $20 \mathrm{ng} / \mathrm{mL}$ epidermal growth factor (BD Biosciences, San Jose, CA), basic fibroblast growth factor and $4 \mathrm{mg} / \mathrm{mL}$ insulin (Sigma) and plated at $5 \times 10^{3}$ cells (BC, BSW, and H460) or $1 \times 10^{4}$ cells (SAC and SASW) in ultralow adherent 24-well plates (Corning, Corning, NY). Cells were cultured for two or three weeks. In order to assess the self-renewing property of cells, spheres were collected by gentle centrifugation, dissociated into single cell suspensions, filtered and cultured under conditions described above (second spheres).

\section{Side population analysis and isolation}

Cells were detached by trypsinization and $1 \times 10^{6}$ cells were labeled with $5 \mu \mathrm{g} / \mathrm{mL}$ of Hoechst 33342 in DMEMF12 medium containing 2\% FBS in the presence or absence of $25 \mu \mathrm{M}$ ABCG2 inhibitor fumitremorgin C (FTC; EMD Biosciences, San Diego, CA) at $37^{\circ} \mathrm{C}$ for 90 minutes. The cells were then centrifuged and resuspended in icecold Hank's buffer salt solution (HBSS). SP analysis and sorting were performed using BD FACSAria fluorescenceactivating (flow cytometry)-based cell sorter (BD Biosciences). The Hoechst dye was excited with a UV laser and its fluorescence was measured with both a 450/20 filter (Hoechst Blue) and 675 LP filter (Hoechst Red). SP fraction was calculated based on the disappearance of SP cells in the presence of FTC using the formula: SP percentage in the absence of FTC - SP percentage in the presence of FTC.

\section{Apoptosis assay}

Apoptosis was determined by DNA condensation/fragmentation assay using Hoechst 33342 dye. Cells were incubated with $10 \mu \mathrm{g} / \mathrm{mL}$ of Hoechst 33342 for 30 minutes and visualized under a fluorescence microscope (Leica Microsystems, Bannockburn, IL). Cells having intensely condensed and/or fragmented nuclei were considered apoptotic. Approximately 1000 nuclei from 10 random fields were analyzed for each sample. The apoptotic index was calculated as the percentage of cells with apoptotic nuclei over total number of cells.

\section{Cell migration and invasion assays}

In vitro cell migration and invasion were determined using a 24-well Transwell ${ }^{\circledR}$ unit with polycarbonate (PVDF) filters (8- $\mu \mathrm{m}$ pore size). The membrane was coated with Matrigel ${ }^{\ominus}$ (BD Biosciences, NJ) for the invasion assay, while control inserts were used for the migration assay. Briefly, cells at the density of $3 \times 10^{4}$ cells per well (invasion) or $1.5 \times 10^{4}$ cells per well (migration) were seeded into the upper chamber of the Transwell $^{\odot}$ unit in serum-free medium. The lower chamber of the unit was filled with a normal growth medium containing 5\% FBS. Chambers were incubated at $37^{\circ} \mathrm{C}$ in a $5 \% \mathrm{CO}_{2}$ atmosphere for 48 hours. 
The non-migrating or non-invading cells were removed from the inside of the insert with a cotton swab. Cells that migrated or invaded to the underside of the membrane were fixed and stained with $10 \mu \mathrm{g} / \mathrm{mL}$ Hoechst 33342 for 30 minutes. Inserts were visualized and scored under a fluorescence microscope (Leica DM, IL).

\section{Xenograft mouse model}

Animal care and experimental procedures described in this study were performed in accordance with the Guidelines for Animal Experiments at West Virginia University with the approval of the Institutional Animal Care and Use Committee (IACUC \#12-0502). Immunodeficient NOD/SCID gamma mice, strain NOD.Cg-Prkdc scid Il2rg ${ }^{\text {tm1Wjl } / S z J ~(N S G ; ~ J a c k s o n ~ L a b o r a t o r y, ~ B a r ~ H a r b o r, ~}$ $\mathrm{ME})$, were maintained under pathogen-free conditions within the institutional animal facility. Food and tap water were given ad libitum. Mice were subcutaneously injected with $5 \times 10^{3}-1 \times 10^{5}$ sorted SP and NSP cells derived from the transformed BSW, positive control H460 cells, or passage-control BC cells suspended in $100 \mu \mathrm{L}$ of Extra$\mathrm{Cel}^{\circledR}$ hydrogel (Advanced BioMatrix, San Diego, CA). Mice were inspected daily for any signs of distress such as weight loss, hunching, failure to groom, and red discharge from the eyes. Tumor growth was monitored daily and tumor size was measured at 21, 28 and 35 days postinjection by using an external caliper (VWR International, Batavia, IL). Tumor volume was calculated using the formula: tumor volume $\left[\mathrm{mm}^{3}\right]=1 / 2$ (length $\left.[\mathrm{mm}]\right) \times($ width $\left.[\mathrm{mm}]^{2}\right)$. At the end of experiments, mice were euthanized and tumors were dissected and weighted.

\section{Tumor histopathology}

Tumor samples from each tumor were formalin-fixed and paraffin-embedded. Tumor specimens were cut into $5-\mu \mathrm{m}$ sections and stained with hematoxylin and eosin (H\&E) to define the morphology and cellular structure within the tumor region. All tissue sectioning and staining were performed at the West Virginia University Pathology Laboratory for Translational Medicine. The presence of multinucleated cells and condensation of heterochromatin (hematoxylin staining) were considered as cancer-specific patterns.

\section{Human stem cell array}

The Proteome Profiler ${ }^{\mathrm{TM}}$ array of human pluripotent stem cell array was commercially obtained from R\&D Systems (Minneapolis, MN) and was used according to the manufacturer's instruction. Briefly, a total of $150 \mu \mathrm{g}$ of protein lysates were incubated overnight with nitrocellulose membranes dotted with duplicate spots for 15 stem cell markers and control antibodies. Bound proteins were detected with horseradish peroxidase (HRP)-conjugated antibodies using a chemiluminescence detection system
(Amersham Biosciences, Piscataway, NJ) and quantified using analyst/PC densitometry software.

\section{Western blot analysis}

After specific treatments, cells were incubated in lysis buffer containing $20 \mathrm{mM}$ Tris- $\mathrm{HCl}$ ( $\mathrm{pH} 7.5)$, 1\% Triton $\mathrm{X}-100,150 \mathrm{mM} \mathrm{NaCl}, 10 \%$ glycerol, $1 \mathrm{mM} \mathrm{Na} \mathrm{VO}_{4}$, $50 \mathrm{mM} \mathrm{NaF}, 100 \mathrm{mM}$ phenylmethylsulfonyl fluoride, and a commercial protease inhibitor mixture (Roche Molecular Biochemicals, Indianapolis, IN) at $4^{\circ} \mathrm{C}$ for 20 minutes. The lysate was collected and determined for protein content using the Bradford method (Bio-Rad Laboratories, Hercules, CA). Proteins $(40 \mu \mathrm{g})$ were resolved under denaturing conditions by $7.5-12 \%$ sodium dodecyl sulfate-polyacrylamide gel electrophoresis (SDS-PAGE) and transferred onto nitrocellulose membranes (Bio-Rad). The transferred membranes were blocked for 1 hour in $5 \%$ nonfat dry milk in TBST (25 mM Tris- $\mathrm{HCl}, \mathrm{pH} 7.4$, $125 \mathrm{mM} \mathrm{NaCl}, 0.05 \%$ Tween 20) and incubated with the appropriate primary antibodies at $4^{\circ} \mathrm{C}$ overnight. Membranes were washed twice with TBST for 10 minutes and incubated with HRP-coupled isotype-specific secondary antibodies for 1 hour at room temperature. The immune complexes were detected by an enhanced chemiluminescence detection system and quantified using analyst/PC densitometry software.

\section{Stem cell surface marker analysis}

Cells were detached by trypsinization and $2 \times 10^{5}$ cells in $100 \mu \mathrm{L}$ of FACS buffer were labeled with $10 \mu \mathrm{L}$ of fluorochrome-conjugated antibodies against CD24, CD44, and CD133 (Miltenyi Biotec) in a dark refrigerator for 15 minutes. The cells were then washed, fixed in $2 \%$ paraformaldehyde, and resuspended in FACS buffer for analysis by flow cytometry.

\section{Statistical analysis}

The data represent means \pm SD from three or more independent experiments as indicated. Statistical analysis was performed by Student's $t$ test at a significance level of $p<0.05$.

\begin{abstract}
Abbreviations
CNT: Carbon nanotubes; SWCNT: Single-walled CNT; CSC: Cancer stem cells; FACS: Fluorescence-activated cell sorting; SP: Side population; NSP: Non-SP; BC: Passage-matched control bronchial epithelial cells; BSW: Chronic SWCNT-exposed bronchial epithelial cells; SAC: Passage-matched control small airway epithelial cells; SASW: Chronic SWCNT-exposed small airway epithelial cells; SAAB: Chronic asbestos-exposed small airway epithelial cells; SSC: Side-scattered light; FSC: Forward-scattered light; NSG mice: NOD/SCID gamma mice; H\&E: Hematoxylin and eosin; E-Cad: E-cadherin; WT: Wild-type.
\end{abstract}

\section{Competing interests}

The authors declare that they have no potential competing interests.

\section{Authors' contributions}

SL designed research, carried out molecular and functional assays, animal studies, and prepared the manuscript. LW characterized particles and 
performed chronic exposure. VC participated in the design of the study and prepared the manuscript. YR conceived and coordinated the project, and prepared the manuscript. All authors read and approved the final manuscript.

\section{Authors' information}

This work was supported by the NIH Grants R01-HL095579 and R01-ES022968, NSF Grant EPS-1003907, and MBRCC, Sara C. Allen and James F. Allen Comp Lung Cancer Research Fund.

\section{Acknowledgements \\ This work was supported by the National Institute for Occupational Safety and Health and by grants from the National Institutes of Health (R01-ES022968 and R01-HL095579), National Science Foundation (EPS-1003907), and Mary Babb Randolph Cancer Center (MBRCC) Sara C. Allen Lung and James F. Allen Comp Lung Cancer Research Fund. Flow cytometric analysis was performed in the West Virginia University Flow Cytometry Core Facility, which is supported in part by National Institutes of Health Grant P30 GM103488. Animal experiments were performed in the West Virginia University Animal Models and Imaging Facility, which is supported in part by the Mary Babb Randolph Cancer Center and National Institutes of Health Grants P20 RR016440, P30 RR032138/GM103488 and S10 RR026378. The authors would like to acknowledge the West Virginia University Pathology Laboratory for Translational Medicine for tissue sectioning and staining service, and its Director Dr. James Coad for his help with tumor histopathology. The authors also thank Jingting Li for her excellent technical assistance.}

\section{Disclaimer}

The findings and conclusions in this report are those of the authors and do not necessarily represent the views of the National Institute for Occupational Safety and Health.

\section{Author details}

${ }^{1}$ Pharmaceutical and Pharmacological Sciences Program, West Virginia University, Morgantown, WV 26506, USA. ${ }^{2}$ Mary Babb Randolph Cancer Center, West Virginia University, Morgantown, WV 26506, USA. ${ }^{3}$ Pathology and Physiology Research Branch, National Institute for Occupational Safety and Health, Morgantown, WV 26505, USA.

Received: 27 November 2013 Accepted: 5 May 2014 Published: 11 May 2014

\section{References}

1. Shvedova AA, Kisin ER, Porter D, Schulte P, Kagan VE, Fadeel B, Castranova $V$ : Mechanisms of pulmonary toxicity and medical applications of carbon nanotubes: two faces of Janus? Pharmacol Ther 2009, 121:192-204.

2. Helland A, Wick P, Koehler A, Schmid K, Som C: Reviewing the environmental and human health knowledge base of carbon nanotubes. Environ Health Perspect 2007, 115:1125-1131.

3. Snyder-Talkington BN, Schwegler-Berry D, Castranova V, Qian Y, Guo NL: Multi-walled carbon nanotubes induce human microvascular endothelial cellular effects in an alveolar-capillary co-culture with small airway epithelial cells. Part Fibre Toxicol 2013, 10:35

4. Donaldson K, Aitken R, Tran L, Stone V, Duffin R, Forrest G, Alexandra A: Carbon nanotubes: a review of their properties in relation to pulmonary toxicology and workplace safety. Toxicol Sci 2006, 92:5-22.

5. Jaurand MCF, Renier A, Daubriac J: Mesothelioma: do asbestos and carbon nanotubes pose the same health risk? Part Fibre Toxicol 2009, 6:16.

6. Shvedova AA, Kapralov AA, Feng WH, Kisin ER, Murray AR, Mercer RR, St Croix CM, Lang MA, Watkins SC, Konduru NV, Allen BL, Conroy J, Kotchey GP, Mohamed BM, Meade AD, Volkov Y, Star A, Fadeel B, Kagan VE: Impaired clearance and enhanced pulmonary inflammatory/fibrotic response to carbon nanotubes in myeloperoxidase-deficient mice. PLOS One 2012, 7:e30923.

7. Mercer RR, Scabilloni J, Wang L, Kisin E, Murray AR, Schwegler-Berry D, Shvedova AA, Castranova V: Alteration of deposition pattern and pulmonary response as a result of improved dispersion of aspirated single-walled carbon nanotubes in a mouse model. Am J Physiol Lung Cell Mol Physiol 2008, 294:L87-L97.

8. Shvedova AA, Kisin ER, Mercer R, Murray AR, Johnson VJ, Potapovich AL, Tyurina YY, Gorelik O, Arepalli S, Schwegler-Berry D, Hubbs AF, Antonini J, Evans DE, Ku BK, Ramsey D, Maynard A, Kagan VE, Castranova V, Baron P:
Unusual inflammatory and fibrogenic pulmonary responses to single-walled carbon nanotubes in mice. Am J Physiol Lung Cell Mol Physiol 2005, 289:L698-L708.

9. Mercer RR, Hubbs AF, Scabilloni JF, Wang L, Battelli LA, Schwegler-Berry D, Castranova V, Porter DW: Distribution and persistence of pleural penetrations by multi-walled carbon nanotubes. Part Fibre Toxicol 2010, 7:28.

10. Mercer RR, Hubbs AF, Scabilloni JF, Wang L, Battelli LA, Castranova V, Porter DW: Pulmonary fibrotic response from inhaled multiwalled carbon nanotube exposure in mice. The Toxicologist 2012, 126:A1806.

11. Donaldson K, Murphy FA, Duffin R, Poland CA: Asbestos, carbon nanotubes and the pleural mesothelium: a review of the hypothesis regarding the role on long fibre retention in the parietal pleura, inflammation and mesothelioma. Part Fibre Toxicol 2010, 7:5.

12. Bernstein DM, Riego Sintes JM, Kjaer Ersboell B, Kunert J, Riego Sintes JM, Kjaer Ersboell B, Kunert J, Riego Sintes JM, Kjaer Ersboell B, Kunert J: Biopersistence of synthetic mineral fibers as a predictor of chronic intraperitoneal injection tumour response in rats. Inhal Toxicol 2001, 13:851-875.

13. Hesterberg TW, Chase G, Axten C, Miller WC, Musselman RP, Kamstrup O, Hadley J, Morscheldt C, Bernstein DM, Thevenaz P: Biopersistence of synthetic vitreous fibers and amosite asbestos in the rat lung following inhalation. Toxicol Appl Pharmacol 1998, 151:262-275.

14. Davoren M, Herzog E, Casey A, Cottineau B, Chambers G, Byrne HJ, Lyng FM: In vitro toxicity evaluation of single walled carbon nanotubes on human A549 lung cells. Toxicol in Vitro 2007, 21:438-448.

15. Lindberg HK, Falck GC, Suhonen S, Vippola M, Vanhala E, Catalan J, Savolainen K, Norppa H: Genotoxicity of nanomaterials: DNA damage and micronuclei induced by carbon nanotubes and graphite nanofibres in human bronchial epithelial cells in vitro. Toxicol Lett 2009, 186:166-173.

16. Sargent LM, Shvedova AA, Hubbs AF, Salisbury JL, Benkovic SA, Kashon ML, Lowry DT, Murray AR, Kisin ER, Friend S, McKinstry KT, Battelli L, Reynolds SH: Induction of aneuploidy by single-walled carbon nanotubes. Environ Mol Mutagen 2009, 50:708-717.

17. Pacurari M, Yin XJ, Zhao J, Ding M, Leonard SS, Schwegler-Berry D, Ducatman BS, Sbarra D, Hoover MD, Castranova V, Vallyathan V: Raw single-wall carbon nanotubes induce oxidative stress and activate MAPKs, AP-1, NF-kappaB, and Akt in normal and malignant human mesothelial cells. Environ Health Perspect 2008, 116:1211-1217.

18. Chou CC, Hsiao HY, Hong QS, Chen CH, Peng YW, Chen HW, Yang PC: Single-walled carbon nanotubes can induce pulmonary injury in mouse model. Nano Lett 2008, 8:437-445.

19. Takagi A, Hirose A, Nishimura T, Fukumori N, Ogata A, Ohashi N, Kitajima S, Kanno J: Induction of mesothelioma in p53+/- mouse by intraperitoneal application of multi-wall carbon nanotube. J Toxicol Sci 2008, 33:105-116.

20. Kanno J, Takagi A, Nishimura T, Hirose A: Mesothelioma induction by micrometer-sized multi-walled carbon nanotube intraperitoneally injected to p53 heterozygous mice. Toxicologist 2010, 114:A1397.

21. Poland CA, Duffin R, Kinloch L, Maynard A, Wallace WAH, Seaton A, Stone V, Brown S, MacNee W, Donaldson K: Carbon nanotubes introduced into the abdominal cavity of mice show asbestos-like pathogenicity in a pilot study. Nat Nanotechnol 2008, 3:423-428.

22. Shvedova AA, Kisin E, Murray AR, Johnson VJ, Gorelik O, Arepalli S, Hubbs AF, Mercer RR, Keohavong P, Sussman N, Jin J, Yin J, Stone S, Chen BT, Deye G, Maynard A, Castranova V, Baron PA, Kagan VE: Inhalation vs. aspiration of single-walled carbon nanotubes in C57BL/6 mice: inflammation, fibrosis, oxidative stress, and mutagenesis. Am J Physiol Lung Cell Mol Physiol 2008, 295:L552-L565.

23. Shukla A, Vacek P, Mossman BT: Dose-response relationships in expression of biomarkers of cell proliferation in in vitro assays and inhalation experiments. Nonlinearity Biol Toxicol Med 2004, 2:117-128.

24. Wang L, Luanpitpong S, Castranova V, Tse W, Lu Y, Pongrakhananon V, Rojanasakul $Y$ : Carbon nanotubes induce malignant transformation and tumorigenesis of human lung epithelial cells. Nano Lett 2011, 11:2796-2803.

25. Wang L, Stueckle T, Mishra A, Derk R, Meighan T, Castranova V, Rojanasakul Y: Neoplastic-like transformation effect of single-walled and multi-walled carbon nanotubes compared to asbestos on human lung small airway epithelial cells. Nanotoxicology 2014, 8:485-507.

26. Lohchareonkal W, Wang L, Stueckle T, Dinu CZ, Castranova V, Liu Y, Rojanasakul Y: Chronic exposure to carbon nanotubes induces invasion 
of human mesothelial cells through matrix metalloproteinase-2. ACS Nano 2013, 7:7711-7723.

27. Ailles LE, Weissman IL: Cancer stem cells in solid tumors. Curr Opin in Biotech 2007, 18:460-466.

28. Dalerba P, Cho RW, Clarke MF: Cancer stem cells: models and concepts. Annu Rev Med 2007, 58:267-284.

29. Christgen M, Geffers R, Ballmaier M, Christgen H, Poczkaj J, Krech T, Kreipe $H$, Lehmann U: Down-regulation of the fetal stem cell factor sox 17 by H33342: a mechanism responsible for differential gene expression in breast cancer side population cells. J Biol Chem 2010, 285:6412-6418.

30. Ho MM, Ng AV, Lam S, Hung JY: Side population in human lung cancer cell lines and tumors is enriched with stem-like cancer cells. Cancer Res 2007, 67:4827-4833.

31. Levina V, Marrangoni AM, DeMarco R, Gorelik E, Lokshin AE: Drug-selected human lung cancer stem cells: cytokine network, tumorigenic and metastatic properties. PLoS One 2008, 3:e3077.

32. Wang L, Castranova V, Mishra A, Chen B, Mercer RR, Schwegler-Berry D, Rojanasakul Y: Dispersion of single-walled carbon nanotubes by a natural lung surfactant for pulmonary in vitro and in vivo toxicity studies. Part Fibre Toxicol 2010, 7:31.

33. Stone KC, Mercer RR, Gehr P, Stockstill B, Crapo JD: Allometric relationships of cell numbers and size in the mammalian lung. Am J Respir Cell Mol Biol 1992, 6:235-243.

34. Han JH, Lee EJ, Lee JH, So KP, Lee YH, Bae GN, Lee SB, Ji JH, Cho MH, Yu IJ: Monitoring multiwalled carbon nanotube exposure in carbon nanotube research facility. Inhal Toxicol 2008, 20:741-749.

35. Erdely A, Dahm M, Chen BT, Birch ME, Evans DE, Schubauer-Berigan M, Hulderman T, Bilgesu SA, Leonard HD, McKinney W, Frazer DG, Antonini JM, Porter DW, Castranova V, Schubauer-Berigan MK: Carbon nanotube dosimetry: from workplace exposure assessment to inhalation toxicology. Part Fibre Toxicol 2013, 10:53.

36. Levina V, Marrangoni A, Wang T, Parikh S, Su Y, Herberman R, Lokshin A, Gorelik E: Elimination of human lung cancer stem cells through targeting of the stem cell factor-c-kit autocrine signaling loop. Cancer Res 2010, 70:338-346.

37. Colburn NH, Bruegge WF, Bates JR, Gray RH, Rossen JD, Kelsey WH, Shimada T: Correlation of anchorage-independent growth with tumorigenicity of chemically transformed mouse epidermal cells. Cancer Res 1978, 38:624-634.

38. Dontu G, Abdallah WM, Foley JM, Jackson KW, Clarke MF, Kawamura MJ, Wicha MS: In vitro propagation and transcriptional profiling of human mammary stem/progenitor cells. Genes Dev 2003, 17:1253-1270.

39. Romano AC, Espana EM, Yoo SH, Budak MT, Wolosin JM, Tseng SC: Different cell sizes in human limbal and central corneal basal epithelia measured by confocal microscopy and flow cytometry. Ophthalmol Vis Sci 2003, 44:5125-5129.

40. Mitsutake N, Iwao A, Nagai K, Namba H, Ohtsuru A, Saenko V, Yamashita S: Characterization of side population in thyroid cancer cell lines: cancer stem-like cells are enriched partly but not exclusively. Endocrinology 2007, 148:1797-1803.

41. Kruyt FA, Schuringa JJ: Apoptosis and cancer stem cells: Implications for apoptosis targeted therapy. Biochem Pharmacol 2010, 80:423-430.

42. Friedl $P$, Wolf K: Tumour-cell invasion and migration: diversity and escape mechanisms. Nat Rev Cancer 2003, 3:362-374

43. Ullmann R, Bongiovanni M, Halbwedl I, Petzmann S, Gogg-Kammerer M, Sapino A, Papotti M, Bussolati G, Popper HH: Bronchiolar columnar cell dysplasia-genetic analysis of a novel preneoplastic lesion of peripheral lung. Virchows Arch 2003, 442:429-436.

44. Jaggupilli A, Elkord E: Significance of CD44 and CD24 as cancer stem cell markers: an enduring ambiguity. Clin Dev Immunol 2012, 2012:708036.

45. Mizugaki H, Sakakibara-Konishi J, Kikuchi J, Moriya J, Hatanaka KC, Kikuchi E, Kinoshita I, Oizumi S, Dosaka-Akita H, Matsuno Y, Nishimura M: CD133 expression: a potential prognostic marker for non-small cell lung cancers. Int J Oncol 2013. doi:10.1007/s10147-013-0541-x.

46. Samel JM: Environmental causes of cancer: what do we know in 2003 ? Chest 2004, 125:80S-83S.

47. Samet JM, Avila-Tang E, Boffetta P, Hannan LM, Olivo-Marston S, Thun MJ, Rudin CM: Lung cancer in never smokers: clinical epidemiology and environmental risk factors. Clin Cancer Res 2009, 15:5625-5645.

48. Singh SK, Hawkins C, Clarke ID, Squire JA, Bayani J, Hide T, Henkelman RM, Cusimano MD, Dirks PB: Identification of human brain tumour initiating cells. Nature 2004, 432:396-401.
49. Jia G, Wang H, Yan L, Wang X, Pei R, Yan T, Zhao Y, Guo X: Cytotoxicity of carbon nanomaterials: single-wall nanotube, multi-wall nanotube, and fullerene. Environ Sci Technol 2005, 39:1378-1383.

50. Tian F, Cui D, Schwarz H, Estrada GG, Kobayashi H: Cytotoxicity of single-wall carbon nanotubes on human fibroblasts. Toxicol In Vitro 2006, 20:1201-1212

51. Hu X, Cook S, Wang P, Hwang HM, Liu X, Williams QL: In vitro evaluation of cytotoxicity of engineered carbon nanotubes in selected human cell lines. Sci Total Environ 2010, 408:1812-1817.

52. Mercer RR, Hubbs AF, Scabilloni JF, Wang L, Battelli LA, Friend S, Castranova $\checkmark$, Porter DW: Pulmonary fibrotic response to aspiration of multi-walled carbon nanotubes. Part Fibre Toxicol 2011, 8:21.

53. Hanahan D, Weinberg RA: The hallmarks of cancer. Cell 2000, 100:57-70.

54. Gatenby RA, Gillies RJ: A microenvironmenal model of carcinogenesis. Nat Rev Cancer 2008, 8:56-61.

55. Mieault MM, Hauke R, Mehta PP, Batra SK: Recent advances in cancer stem/ progenitor cell research: therapeutic implications for overcoming resistance to the most aggressive cancers. J Cell Mol Med 2007, 11:981-1011.

56. Stenner-Liewen F, Reed JC: Apoptosis and cancer: basic mechanisms and therapeutic opportunities in the postgenomic era. Cancer Res 2003, 63:263-268.

57. Gupta GP, Massague J: Cancer metastasis: building a framework. Cell 2006, 127:679-695.

58. Noh KH, Kim BW, Song KH, Cho H, Lee YH, Kim JH, Chung JY, Kim JH, Hewitt SM, Seong SY, Mao CP, WU TC, Kim TW: Nanog signaling in cancer promotes stem-like phenotype and immune evasion. J Clin Invest 2012, 122:4077-4093.

59. Jeter CR, Liu B, Liu X, Chen X, Liu C, Calhoun-Davis T, Repass J, Zaehres H, Shen JJ, Tang DG: NANOG promotes cancer stem cell characteristics and prostate cancer resistance to androgen deprivation. Oncogene 2011 30:3833-3845.

60. Chen S, Xu Y, Chen Y, Li X, Mou W, Wang L, Liu Y, Reisfeld RA, Xiang R, LV $D$, Li N: SOX2 gene regulates the transcriptional network of oncogenes and affects tumorigenesis of human lung cancer cells. PLoS One 2012, 7:e36326.

61. Xiang R, Liao D, Cheng T, Zhou H, Shi Q, Chuang TS, Markowitz D, Reisfeld RA, Luo Y: Downregulation of transcription factor SOX2 in cancer stem cells suppresses growth and metastasis of lung cancer. Br J Cancer 2011 104:1410-1417.

62. Akunuru S, James Zhai O, Zheng Y: Non-small cell lung cancer stem/ progenitor cells are enriched in multiple distinct phenotypic subpopulations and exhibit plasticity. Cell Death Dis 2012, 3:e352.

63. Wei W, Hu H, Tan H, Chow LW, Yip AY, Loo WT: Relationship of CD44 + CD24-/low breast cancer stem cells and axillary lymph node metastasis. J Transl Med 2012, 10:S6.

64. Chen YC, Hsu HS, Chen YW, Tsai TH, How CK, Wang CY, Hung SC, Chang YL, Tsai ML, Lee YY, Ku HH, Chiou SH: Oct-4 expression maintained cancer stem-like properties in lung cancer-derived CD133-positive cells. PLOS One 2008, 3:e2637.

65. Bertolinia G, Roz L, Perego P, Tortoreto M, Fontanella E, Gatti L, Pratesi G, Fabbri A, Andriani F, Tinelli S, Roz E, Caserini R, Lo Vullo S, Camerini T, Mariani L, Delia D, Calabro E, Pastorino U, Sozzi G: Highly tumorigenic lung cancer $\mathrm{CD} 133^{+}$cells display stem-like features and are spared by cisplatin treatment. Proc Natl Acad Sci U S A 2009, 106:16281-16286.

66. lida H, Suzuki M, Goitsuka R, Ueno H: Hypoxia induces CD133 expression in human lung cancer cells by up-regulation of OCT3/4 and SOX2. Int J Oncology 2012, 40:71-79.

67. Ozaki T, Nakagawara A: Role of p53 in cell death and human cancers. Cancers 2011, 3:994-1013.

68. Piao CQ, Liu L, Zhao YL, Balajee AS, Suzuki M, Hei TK: Immortalizaiton of human small airway epithelial cells by ectopic expression of telomerase. Carcinogenesis 2005, 26:725-731.

69. Clark GJ, Cox AD, Graham SM, Der CJ: Biological assays for Ras transformation. Methods Enzymol 1995, 255:395-412.

doi:10.1186/1743-8977-11-22

Cite this article as: Luanpitpong et al:: Induction of stem-like cells with malignant properties by chronic exposure of human lung epithelial cells to single-walled carbon nanotubes. Particle and Fibre Toxicology $201411: 22$ 